\title{
Article
}

\section{Sulfur-bearing monazite-(Ce) from the Eureka carbonatite, Namibia: oxidation state, substitution mechanism, and formation conditions}

\author{
Sam Broom-Fendley ${ }^{1 \star}$ (D), Martin P Smith², Marcelo B Andrade ${ }^{3}$ (D), Santanu Ray ${ }^{2}$, David A Banks ${ }^{4}$, Edward Loye ${ }^{1,5}$, \\ Daniel Atencio ${ }^{6}$ (D), Jonathan R Pickles ${ }^{1}$ and Frances Wall ${ }^{1}$ (D) \\ ${ }^{1}$ Camborne School of Mines and the Environment and Sustainability Institute, University of Exeter, Penryn Campus, Cornwall TR10 9FE, UK; ${ }^{2}$ School of Environment \\ and Technology, University of Brighton, Cockcroft Building, Lewes Road, Brighton BN4 2GJ, UK; ${ }^{3}$ São Carlos Institute of Physics, University of São Paulo, PO Box 369 , \\ 13560-970, São Carlos, SP, Brazil; ${ }^{4}$ School of Earth and Environment, University of Leeds, Leeds LS2 9JT, UK; ${ }^{5} \mathrm{E}$-Tech Metals Ltd., Woodlands Grange, Bradley Stoke, \\ Bristol BS32 4JY, UK; and ${ }^{6}$ Departamento de Mineralogia e Geotectônica, Instituto de Geociências, Universidade de São Paulo, Rua do Lago 562, 05508-080 São \\ Paulo, SP, Brazil
}

\begin{abstract}
Sulfur-bearing monazite-(Ce) occurs in silicified carbonatite at Eureka, Namibia, forming rims up to $\sim 0.5 \mathrm{~mm}$ thick on earlier-formed monazite-(Ce) megacrysts. We present X-ray photoelectron spectroscopy data demonstrating that sulfur is accommodated predominantly in monazite-(Ce) as sulfate, via a clino-anhydrite-type coupled substitution mechanism. Minor sulfide and sulfite peaks in the $\mathrm{X}$-ray photoelectron spectra, however, also indicate that more complex substitution mechanisms incorporating $\mathrm{S}^{2-}$ and $\mathrm{S}^{4+}$ are possible. Incorporation of $S^{6+}$ through clino-anhydrite-type substitution results in an excess of $M^{2+}$ cations, which previous workers have suggested is accommodated by auxiliary substitution of $\mathrm{OH}^{-}$for $\mathrm{O}^{2-}$. However, Raman data show no indication of $\mathrm{OH}^{-}$, and instead we suggest charge imbalance is accommodated through $\mathrm{F}^{-}$substituting for $\mathrm{O}^{2-}$. The accommodation of $\mathrm{S}$ in the monazite-(Ce) results in considerable structural distortion that may account for relatively high contents of ions with radii beyond those normally found in monazite-(Ce), such as the heavy rare earth elements, Mo, Zr and V. In contrast to S-bearing monazite-(Ce) in other carbonatites, S-bearing monazite-(Ce) at Eureka formed via a dissolution-precipitation mechanism during prolonged weathering, with $\mathrm{S}$ derived from an aeolian source. While large S-bearing monazite- $(\mathrm{Ce})$ grains are likely to be rare in the geological record, formation of secondary S-bearing monazite-(Ce) in these conditions may be a feasible mineral for dating palaeo-weathering horizons.
\end{abstract}

Keywords: sulfur-bearing monazite-(Ce), redox, carbonatite, silcrete, calcrete, weathering

(Received 31 August 2019; accepted 4 December 2019; Accepted Manuscript published online: 11 December 2019; Guest Editor: Eimear Deady)

\section{Introduction}

The Ce-dominant rare earth element $(R E E)$ phosphate mineral monazite-(Ce) is the most commonly occurring REE-bearing mineral and most abundant species of the monoclinic monazite group. It occurs typically as a small accessory phase in granitic and metamorphic rocks, but reaches larger sizes and higher modal abundancies in some carbonatites, pegmatites, alkaline rocks and metamorphic veins (e.g. Bermanec et al., 1988; Andreoli et al., 1994; Lehmann et al., 1994; Wall and Mariano, 1996; Gonçalves et al., 2016; Broom-Fendley et al., 2017; Montel et al., 2018; Ntiharirizwa et al., 2018; Slezak and Spandler, 2019). Monazite-(Ce) is of considerable importance for both practical and research reasons. It is a major ore mineral for the light (L)REE (and Th) (Chakhmouradian and Wall, 2012; Wall, 2014;

\footnotetext{
*Author for correspondence: Sam Broom-Fendley, Email: s.l.broom-fendley@exeter.ac.uk This paper is part of a thematic set arising from the 3rd International Critical Metals Conference (Edinburgh, May 2019).

Cite this article: Broom-Fendley S., Smith M.P, Andrade M.B, Ray S., Banks D.A, Loye E., Atencio D., Pickles J.R and Wall F. (2020) Sulfur-bearing monazite-(Ce) from the Eureka carbonatite, Namibia: oxidation state, substitution mechanism, and formation conditions. Mineralogical Magazine 84, 35-48. https://doi.org/10.1180/mgm.2019.79
}

Cuney and Kyser, 2015), forming high grade 'hard rock' deposits such as Steenkampskraal, South Africa (Andreoli et al., 1994) and Kangankunde, Malawi (Wall and Mariano, 1996), as well as forming in secondary environments such as laterites (e.g. Mt Weld, Western Australia; Lottermoser, 1990) and heavy mineral sands, both of which are mined. It is also a potential host for long-term storage of radioactive waste (Ewing and Wang, 2002; Oelkers and Montel, 2008), due to its ability to structurally incorporate a variety of actinide elements and resistance to metamictisation (Seydoux-Guillaume et al., 2018).

Monazite-group minerals are used widely as petrochronometers (Engi, 2017). Both Th and $U$ are incorporated readily into the monazite structure, while common $\mathrm{Pb}$ concentrations are typically low, enabling $\mathrm{Th}-\mathrm{Pb}$ and, when $\mathrm{U}$ contents are sufficiently high, $\mathrm{U}-\mathrm{Pb}$ age determination using isotopic (e.g. Parrish, 1990) and nonisotopic techniques such as by electron-probe microanalysis (EPMA; Montel et al., 1996; Williams et al., 2007). Moreover, diffusion of heavy elements is very slow (Cherniak et al., 2004; Gardés et al., 2006, 2007), meaning that inherited cores and individual zones in texturally complex monazite may preserve conditions from multiple, temporally distinct, growth events (Hetherington et al., 2018). Combining geochronological data with other 
geochemical, isotopic and textural details means that the history of rocks formed over multiple episodes can be unravelled (Engi et al., 2017). For example, monazite-(Ce) in equilibrium with xenotime-(Y) (Spear and Pyle, 2002) may be used as a thermometer, constraining $P-T-t$ conditions. Combining $\delta^{18} \mathrm{O}$ (e.g. Ayers et al., 2006) or ${ }^{143} \mathrm{Nd} /{ }^{144} \mathrm{Nd}$ (e.g. McFarlane and McCulloch, 2007) with $\mathrm{Th}-\mathrm{Pb}$ age determination can trace hydrothermal fluid infiltration and mixing between different melt or fluid sources. Textural features, such as oscillatory and sector zoning (e.g. Cressey et al., 1999) may be attributed to magmatic crystallisation, resorption may indicate the presence of a melt with which monazite-(Ce) is not in equilibrium, while development of mineral inclusions, porosity, or mottled textures may be indicative of fluid-mediated dissolution-reprecipitation and therefore ingress of external fluids (Putnis, 2002, 2009; Hetherington et al., 2018).

While rare, the substitution of sulfur into monazite-(Ce) has been described in several localities, predominantly in carbonatites (e.g. Kukharenko et al., 1961; Cressey et al., 1999; Bulakh et al., 2000; Wall, 2004; Enkhbayar et al., 2016; Prokopyev et al., 2017; Nikolenko et al., 2018), but also in kimberlites (Chakhmouradian and Mitchell, 1999), fluid-altered rhyolite (Ondrejka et al., 2007) and in metamorphic rocks (Suzuki and Kato, 2008; Pršek et al., 2010; Krenn et al., 2011; Ondrejka et al., 2016; Laurent et al., 2016). Small amounts of sulfur in monazite-(Ce) and monazite-(La) are also sometimes noted during EPMA radiometric age determination, owing to the close proximity of the $\mathrm{S} K \alpha$ line to the $\mathrm{PbM} \alpha$ lines (Jercinovic and Williams, 2005; Suzuki and Kato, 2008), as well as the association of high $\mathrm{S}$ contents with increased common $\mathrm{Pb}$ (Krenn et al., 2011). Early work predominantly explored substitution mechanisms for incorporating sulfur in monazite-(Ce) (e.g. Chakhmouradian and Mitchell, 1999; Bulakh et al., 2000; Ondrejka et al., 2007), but the presence of sulfur is being used increasingly to infer formation environments. Sulfur incorporation is assumed generally to reflect the introduction of S-bearing fluids in relatively acidic and high $f_{\mathrm{O}_{2}}$ conditions (Pršek et al., 2010; Krenn et al., 2011; Ondrejka et al., 2016; Laurent et al., 2016), possibly at temperatures lower than $400^{\circ} \mathrm{C}$ based on monazite-(Ce)-xenotime-(Y) thermometry (Krenn et al., 2011). Recently, Laurent et al. (2016) showed that it is possible to precisely date $S$ incorporation in monazite-(Ce) and therefore understand the timing of $S$ mobilisation in metamorphic rocks. Their study highlighted the potential to date S-rich domains in monazite-(Ce) from other rock types, such as ore deposits, to further understand the timing of mineralisation. On the basis of co-crystallisation of baryte and the absence of sulfides (e.g. Ondrejka et al., 2007, 2016), it is generally assumed that monazite-(Ce) only incorporates S as the $S^{6+}$ ion, and therefore the presence of $S$-bearing monazite-(Ce) reflects $S$ mobility in oxidising conditions only. However, experimental and $a b$ initio studies have shown that apatite, which has been assumed typically to accommodate sulfur as $S^{6+}$ only (e.g. Pan and Fleet, 2002), is also capable of accommodating more reduced varieties of $S$ such as $\mathrm{S}^{4+}$ and $S^{2-}$ (Konecke et al., 2017a; Kim et al., 2017). There has been no direct investigation into the redox state of $S$ in monazite(Ce) to investigate its capability to accommodate $S$ in different oxidation states. Moreover, the substitution mechanism incorporating $\mathrm{S}$ in monazite-(Ce) remains incompletely understood. These two less-constrained factors reduce our confidence for inferring the formation environment from the presence of $S$ in $L R E E$ phosphate species of the monazite group.
This study presents the first description of S-bearing monazite-(Ce) from the Eureka carbonatite, Namibia. Eureka exhibits the largest grains of S-bearing monazite-(Ce) yet documented $(>0.5 \mathrm{~mm})$ with an $\mathrm{SO}_{3}$ concentration within uncertainty of the highest published $\mathrm{SO}_{3}$ contents $\left[11.23\right.$ wt.\% $\mathrm{SO}_{3} \equiv 0.294 \mathrm{~S}^{6+}$ atoms per formula unit (apfu); cf. Pršek et al., 2010]. The large size of the S-bearing monazite-(Ce) has enabled analysis by $\mathrm{X}$-ray photoelectron spectroscopy (XPS), and we use this technique to present the first direct data on the oxidation state of $S$ in monazite-(Ce). We also expand on previous work investigating $S$ substitution in monazite-(Ce), moving towards a complete, charge-balanced, understanding of the $\mathrm{S}$ substitution mechanism. Lastly, on the basis of the crystallisation environment, we show that sulfur can be incorporated into monazite-(Ce) during a protracted weathering process, opening up the possibility of directly dating palaeo-weathering horizons.

\section{Geology of the Eureka carbonatite}

The Eureka carbonatite is located at $22.044^{\circ} \mathrm{S}, 15.254^{\circ} \mathrm{E}$ on the property of Eureka Farm 99, near Usakos, Namibia (Fig. 1a). Quaternary gravels and calcrete obscure much of the exposure, but remnant mineral exploration trenches from the late 1980s, and modern trenching by E-Tech Metals, facilitates easy sampling. The carbonatites comprise a series of at least four steeplydipping $\left(>75^{\circ}\right)$ monazite-(Ce)-bearing dolomite-carbonatite dykes and at least three monazite-(Ce)-poor dolomite carbonatites and sövites, all striking roughly parallel, (Fig. 1b; von Knorring and Clifford, 1960; Dunai, 1989). The width of the dykes is typically $1-2 \mathrm{~m}$, but may locally reach up to $7 \mathrm{~m}$. The dykes intrude parallel to the foliation of intensely folded Damaran schists and quartzites of the Etusis formation (Miller, 1983, 2008). An ${ }^{87} \mathrm{Sr} /{ }^{86} \mathrm{Sr}$ isotope study supports a mantle origin, with minor crustal input (Dunai et al., 1989).

A distinct feature of the dykes at Eureka is the abundance and size of monazite-(Ce) in the carbonatite. Grains reach up to $30 \mathrm{~cm}$ in size and have been divided by Dunai (1989) by morphology, where (more abundant) larger grains are typically euhedral to subhedral while smaller grains are lenticular and display resorption features. Monazite-(Ce) from Eureka has been dated, by $\mathrm{U}-\mathrm{Pb}$, as $500 \pm 20 \mathrm{Ma}$ (Burger et al., 1965) and $548 \pm 4 \mathrm{Ma}$ (Ragettli et al., 1994; Gonçalves et al., 2018).

Extensive trenching indicates that the area is weathered to at least $2 \mathrm{~m}$ and carbonatite dykes are locally replaced by an assemblage of secondary carbonate minerals, gypsum, serpentine(?), iron oxide/hydroxides, clay and minor fluorite. Locally, the carbonatite is intensely silicified; silicification is most prominent in the north-western area of the intrusion (Zone 2 of Dunai, 1989), with recent drilling indicating that silicification extends to a maximum probable depth of $\sim 5 \mathrm{~m}$. In these rocks, the carbonate matrix has been completely replaced by iron-bearing, rustbrown chalcedony (Fig. 2). Remnant monazite-(Ce) grains in the silicified rocks are typically, although not always, rimmed by a thin (up to $5 \mathrm{~mm}$ ) alteration halo of S-bearing monazite-(Ce), which is the subject of this paper (Fig. 2). The local area is commonly capped by a layer of calcrete $\sim 30 \mathrm{~cm}$ thick.

\section{Samples and methods}

Representative silicified carbonatite samples were collected from Pit 2, in the north-western zone of the deposit (Fig. 1b), where silicification is most intense. Petrographic observations were 

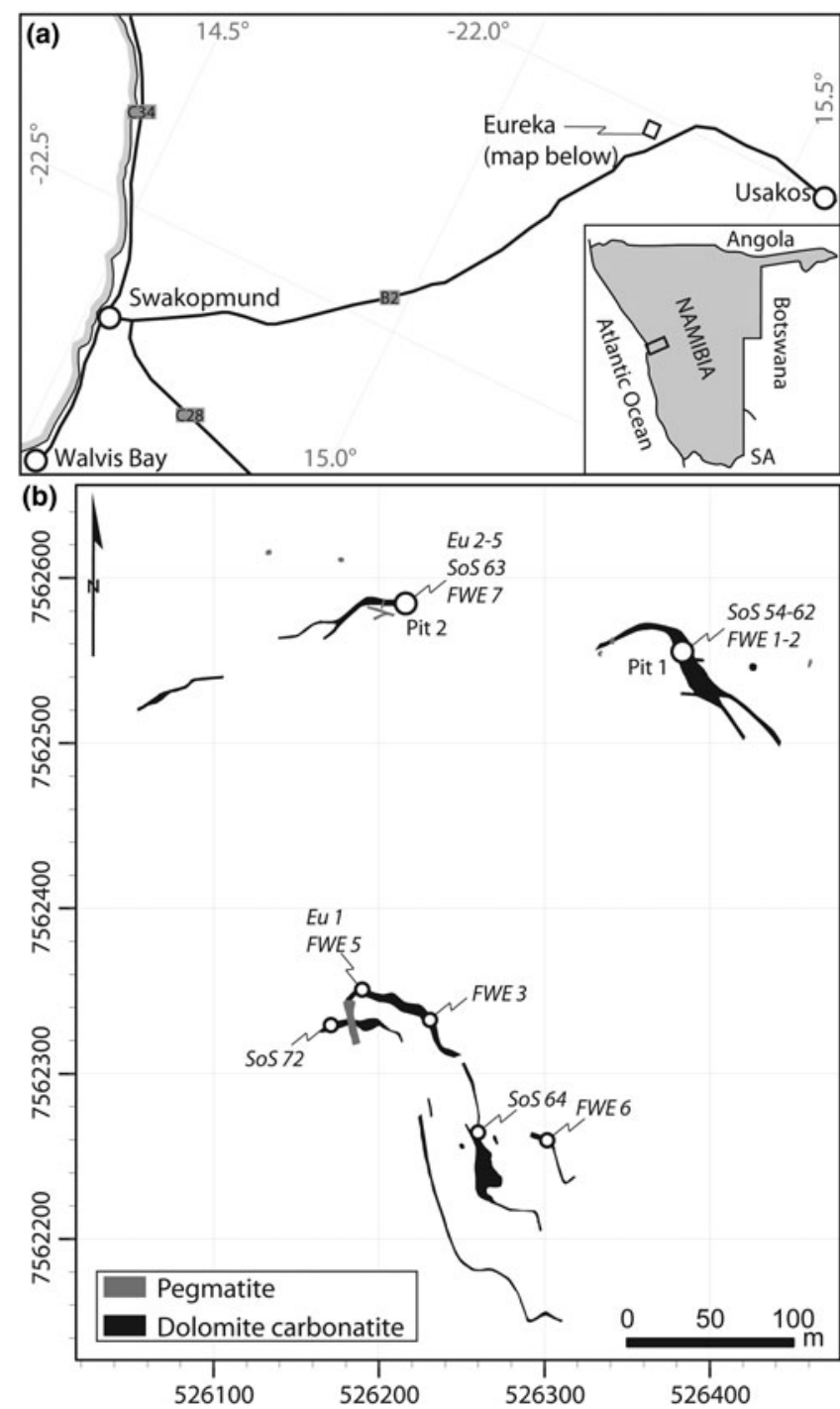

Fig. 1. Location map $(a)$ and geological sketch map $(b)$ of the Eureka carbonatite dykes, with pit and sample locations. Host rocks are quartzite and schists of the Etusis formation. Geological map grid is UTM 33S, WGS 1984 datum, redrawn and georeferenced from Dunai (1989).

undertaken using conventional polarising microscopy and backscattered electron (BSE) imaging. BSE images and maps from energy-dispersive spectroscopy (EDS) were obtained using a FEI Quanta 650 FEG SEM hosted at the Environment and Sustainability Institute, University of Exeter.

Electron probe microanalyses were carried out at Camborne School of Mines on a JEOL JXA-8200 Superprobe, using a defocussed $10 \mu \mathrm{m}, 15 \mathrm{kV}, 50 \mathrm{nA}$ beam. Peak counting times were $20 \mathrm{~s}$ for $\mathrm{S}, \mathrm{Fe}, \mathrm{P}, \mathrm{Ca}$ and $\mathrm{Sr} ; 30 \mathrm{~s}$ for $\mathrm{F}, \mathrm{Na}, \mathrm{Ba}$ and $\mathrm{Ce}$; $40 \mathrm{~s}$ for $\mathrm{Si}, \mathrm{Nd}, \mathrm{La}, \mathrm{Pr}$ and $\mathrm{Sm} ; 60 \mathrm{~s}$ for Th; $100 \mathrm{~s}$ for $\mathrm{Y}$; and $120 \mathrm{~s}$ for Gd. Background count times were half those of the peak value. X-ray counts were converted to wt.\% oxide using the in-built JEOL CITZAF correction program. Empirical interference corrections were performed for the REE following Williams (1996). Correction factors were calculated by measuring the interferences observed on individual REE reference standards. Commercial (Astimex) natural minerals standards were used for all elements except for Th and the REE, where Astimex Th metal and $R E E-\mathrm{Si}-\mathrm{Al}-\mathrm{Ca}-\mathrm{O}$ glasses from the University of

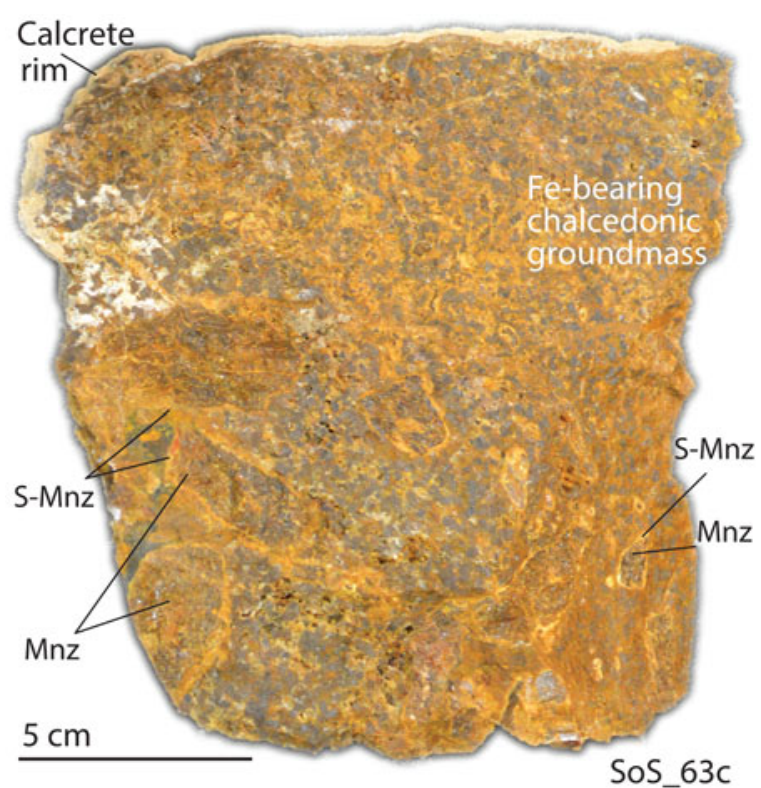

Fig. 2. Example of monazite-(Ce)-bearing (Mnz) silicified carbonatite from Eureka. Note the $\sim 500 \mu \mathrm{m}$ S-bearing monazite-(Ce) rims (S-Mnz) around the monazite-(Ce) grains.

Edinburgh, were used. Representative detection limits are included in Supplementary Table S1.

Laser ablation inductively-coupled plasma mass spectrometry (LA-ICPMS) was carried out at the University of Leeds, using a Lambda Physik $193 \mathrm{~nm}$ ArF Excimer laser coupled to an Agilent 7500 c ICPMS. This was run in reaction mode with $2.5 \mathrm{ml} / \mathrm{min} \mathrm{H}_{2}$ in the reaction cell. The laser utilised a $10 \mathrm{~Hz}$, $25 \mu \mathrm{m}$ spot for $\sim 30 \mathrm{~s}$ of ablation time. Typical fluence was $10 \mathrm{~J} \mathrm{~cm}^{-2}$. Isotopes analysed were: ${ }^{23} \mathrm{Na},{ }^{28} \mathrm{Si},{ }^{31} \mathrm{P},{ }^{32} \mathrm{~S},{ }^{40} \mathrm{Ca},{ }^{47} \mathrm{Ti}$, ${ }^{51} \mathrm{~V},{ }^{56} \mathrm{Fe},{ }^{75} \mathrm{As},{ }^{88} \mathrm{Sr},{ }^{89} \mathrm{Y},{ }^{90} \mathrm{Zr},{ }^{93} \mathrm{Nb},{ }^{65} \mathrm{Mo},{ }^{137} \mathrm{Ba},{ }^{139} \mathrm{La},{ }^{140} \mathrm{Ce}$, ${ }^{141} \mathrm{Pr},{ }^{147} \mathrm{Sm},{ }^{153} \mathrm{Eu},{ }^{157} \mathrm{Gd},{ }^{159} \mathrm{~Tb},{ }^{163} \mathrm{Dy},{ }^{165} \mathrm{Ho},{ }^{166} \mathrm{Er},{ }^{169} \mathrm{Tm}$, ${ }^{172} \mathrm{Yb},{ }^{175} \mathrm{Lu},{ }^{178} \mathrm{Hf},{ }^{208} \mathrm{~Pb},{ }^{232} \mathrm{Th}$ and ${ }^{238} \mathrm{U}$. Data were processed using Iolite software (version 2.5; Paton et al., 2011). Neodymium contents from the EPMA were used as the internal standard value and NIST SRM 610 was used as the external standard. NIST 612 and 614 glasses were utilised as secondary standards, and the concentrations of all analysed elements were within $10 \%$ of the standard values, with most within a $<5 \%$ window.

Raman spectra of $S$ rich and regular monazite-(Ce) were recorded at the University of São Paulo, using a LabRAM HR Evolution micro-Raman system working in back-scattering geometry, using a solid-state laser with a frequency of $633 \mathrm{~nm}$ and, equipped with $1800 \mathrm{gr} / \mathrm{mm}$ gratings, $1 \mathrm{~cm}^{-1}$ spectral resolution and a liquid-nitrogen-cooled CCD detector.

$\mathrm{X}$-ray photoelectron spectroscopy depth profile measurements were conducted using ESCALAB 250xi XPS (Thermo Scientific, UK) with a MAGCISTM Dual Beam Ion Source. Analysis was carried out using the selected area analysis mode with a nominal width of analysis of $200 \mu \mathrm{m}$ and monochromated AlKo X-rays at $1486.6 \mathrm{eV}$. The MAGCIS source can generate both monatomic ion beams for profiling inorganic materials and also cluster ions for organic layer profiling. In this present case on depth profiling monazite-(Ce), the gun was selected in monoatomic mode with $3 \mathrm{keV}$ ion energy and a raster size of $0.5 \mathrm{~mm}$. The sputtering cycle was kept at $120 \mathrm{~s}$ each time. The charge neutraliser and 
X-ray source were only used during the acquisition of spectra, both being turned off during the sputtering cycle. Survey (wide) scans (step size $1 \mathrm{eV}$, pass energy $150 \mathrm{eV}$, dwell time $50 \mathrm{~ms}$, number of scans 15) and narrow scans (step size $0.1 \mathrm{eV}$, pass energy $40 \mathrm{eV}$, dwell time $100 \mathrm{~ms}$, number of scans 25) of the $\mathrm{S} 2 \mathrm{p}$ (binding energy, $\mathrm{BE} \approx 164 \mathrm{eV}), \mathrm{C} 1 \mathrm{~s}(\mathrm{BE} \approx 285 \mathrm{eV}), \mathrm{O} 1 \mathrm{~s}(\mathrm{BE} \approx$ $531 \mathrm{eV}), \mathrm{Ca} 2 \mathrm{p}(\mathrm{BE} \approx 342 \mathrm{eV}), \mathrm{P} 2 \mathrm{p}(\mathrm{BE} \approx 132 \mathrm{eV}), \mathrm{Y} 3 \mathrm{~d}$ $(\mathrm{BE} \approx 153 \mathrm{eV})$, Ce $3 \mathrm{~d}(\mathrm{BE} \approx 884 \mathrm{eV}), \mathrm{La} 3 \mathrm{~d}(\mathrm{BE} \approx 835 \mathrm{eV})$, $\mathrm{Nd} 4 \mathrm{~d}(\mathrm{BE} \approx 120 \mathrm{eV})$ and $\mathrm{Fe} 2 \mathrm{p}(\mathrm{BE} \approx 717 \mathrm{eV})$ regions were acquired. Data analysis were carried out using Thermo Avantage software version 5.952 .

There is a possibility that redox reactions could be induced in the sample as it is sputtered with a mono-atomic argon beam for depth profiling. In order to fully investigate variation in the redox state of elements it was necessary to demonstrate that there was no redox interaction with the ion beam during surface cleaning. A single crystal of apatite from the Slyudjanka mica deposit (Voskoboinikova, 1938), Siberia, Russia, sampled at a depth of $120 \mathrm{~m}$ to avoid weathering effects (provided by J. Kynický) was rastered with the $\mathrm{Ar}^{+}$beam over 31 cycles with narrow scan XPS collected after each cycle. There was no discernible chemical shift in $\mathrm{Ca}$ or $\mathrm{P} 2 \mathrm{p}$ electron binding energies (Supplementary Fig. S1A-B). A similar process was carried out on reagent grade $\mathrm{FeSO}_{4} \cdot n \mathrm{H}_{2} \mathrm{O}$ over 10 raster cycles, again with no discernible chemical shift in the position of the $S 2$ p electron binding energy peak (Supplementary Fig. 1C). From this we conclude that the $\mathrm{Ar}^{+}$rastering process used for surface cleaning and depth profiling preserves robust redox state information in phosphates and for $\mathrm{S}$ species. Tests on homogenous areas of monazite-(Ce) suggest $\mathrm{Ce}^{3+}$ may oxidise to $\mathrm{Ce}^{4+}$ under the $\mathrm{Ar}^{+}$beam, and so Ce narrow scans were analysed following polishing of the sample with no sputtering.

\section{Results}

\section{Petrography}

Silicified carbonatite samples are composed principally of amorphous silica phases, including opal and chalcedony, with minor hematite, calcite and quartz veins. The chalcedony contains abundant inclusions of iron-oxide minerals which and locally follow remnant cleavage planes, intersecting at $60^{\circ}$ and $120^{\circ}$, after the original dolomite crystals (Fig. $3 a$ ). Small (25-50 $\mu \mathrm{m})$ anhedral celestine grains are also distributed randomly within the amorphous silica. Both the iron and strontium from these minerals is likely to be sourced from the breakdown of the original dolomite, which is present in un-silicified samples and contains up to $10 \mathrm{wt} . \% \mathrm{FeO}$ and 3 wt.\% $\mathrm{SrO}$ (unpublished data, Broom-Fendley, 2019).

Monazite- $(\mathrm{Ce})$ in the silicified rocks is texturally similar to large monazite-(Ce) grains in un-silicified rocks. Common features include similar roundness, size (between $\sim 0.1$ and $\sim 7 \mathrm{~cm}$ ), orange colour, and the presence of hematite and rounded dolomite inclusions. However, monazite-(Ce) from the unsilicified samples has a distinct rim of S-bearing monazite-(Ce), up to $500 \mu \mathrm{m}$ wide (e.g. Fig. $3 b-h$ ), and is also commonly crosscut by later silica and hematite veins (Fig. $3 f, i, j$ ). The S-bearing monazite-(Ce) rim is porous and heterogeneous, with iron-oxide minerals (probably hematite) and calcite making up the rest of the assemblage; these non-phosphate minerals are complexly intermixed (Fig. $3 c, f-j$ ). At the margin of monazite-(Ce) grains, $\mathrm{S}$-bearing monazite-(Ce) occurs as rounded, rod-like, globules which are interconnected by thin $<5 \mu \mathrm{m}$ veins, hosted in calcite, akin to a symplectic texture (Fig. $3 c-e$ ). The abundance of calcite intermixed with the S-bearing monazite-(Ce) decreases with increasing distance away from the core monazite- $(\mathrm{Ce})$ grain, reaching a point where S-bearing monazite-(Ce) forms a seemingly homogeneous phase (Fig. $3 g-h)$. Locally, S-bearing monazite-(Ce) is intermixed with Fe-oxide minerals (e.g. Fig. $3 i$ ).

\section{Monazite-(Ce) composition}

Representative EPMA and LA-ICPMS data for monazite-(Ce) and S-bearing monazite-(Ce) from Eureka are shown in Table 1, with the full dataset available in Supplementary Tables S1 and S2. Analysis locations are indicated on Fig. 3. The composition of monazite-(Ce) formed during carbonatite crystallisation is typical, in terms of its relatively low $\mathrm{ThO}_{2}$ and $\mathrm{UO}_{2}$ contents, for monazite-(Ce) from such rocks (cf. Chen et al., 2017). However, chondrite-normalised $R E E$ contents exhibit a small negative Eu and slightly larger negative $\mathrm{Y}$ anomaly (Fig. 4), the former of which is atypical of carbonatite-derived minerals. S-bearing monazite-(Ce) has similar concentrations of $\mathrm{ThO}_{2}$ and $\mathrm{SiO}_{2}$ to the monazite-(Ce) grains, as well as the same $\mathrm{Eu}$ and $\mathrm{Ce}$ anomalies (Fig. 4). However, it has notably different $\mathrm{SO}_{3}(\bar{x} \approx 9.6 \mathrm{wt} . \%), \mathrm{CaO}$ $(\bar{x} \approx 6.6$ wt. $\%)$, SrO $(\bar{x} \approx 4.0$ wt. $\%), \mathrm{FeO}(\bar{x} \approx 1.0$ wt.\%), $\mathrm{F}(\bar{x} \approx$ 0.8 wt.\%) and $\mathrm{Na}_{2} \mathrm{O}(\bar{x} \approx 0.2$ wt.\%) contents, well in excess of the EPMA detection limit (e.g. Fig. $3 g-h)$. Trace elements such as $\mathrm{U}(\bar{x} \approx 210 \mathrm{ppm}), \mathrm{V}(\bar{x} \approx 79 \mathrm{ppm}), \mathrm{Zr}(\bar{x} \approx 22 \mathrm{ppm}), \mathrm{Nb}(\bar{x} \approx$ $10 \mathrm{ppm})$, Mo $(\bar{x} \approx 45 \mathrm{ppm})$ and $\mathrm{Ba}(\bar{x} \approx 159 \mathrm{ppm})$ are also enriched relative to the monazite-(Ce) grains (all below detection except $\mathrm{U}, \bar{x} \approx 80 \mathrm{ppm}, \mathrm{Ba}, \bar{x} \approx 7 \mathrm{ppm})$. Moreover, S-bearing monazite-(Ce) is relatively HREE-enriched, and depleted in La and Ce contents, compared to grains which grew during carbonatite crystallisation.

\section{Oxidation state of sulfur}

The locations of XPS analyses are shown in Fig. 3. Survey scans from binding energies of $0-1350 \mathrm{eV}$ are shown in Fig. 5 . The presence of $S$ is identified clearly in the rim monazite-(Ce), as well as elevated HREE contents, Ca, and F (Fig. 5a,b). Narrow scans were obtained from the Y $3 \mathrm{~d}$ peak as a proxy for the heavy rare earth elements (HREE; Fig. 5b), and sulfur peaks which vary between 160-170 eV, depending on their bonding environment. The peak position at $154 \mathrm{eV}$ is characteristic of $\mathrm{Y}-\mathrm{O}$ bonding in compounds (Mesarwi and Ignatiev, 1993). Deconvolution of the S 2p spectra shows that $\mathrm{S}$ is present dominantly as $\mathrm{SO}_{4}^{2-}(\mathrm{BE} 168.14 \mathrm{eV}$; Yu et al., 1990), but with a component of $\mathrm{S}^{2-}$ (BE $160.25 \mathrm{eV}$; Vasquez, 1991) and $\mathrm{SO}_{3}^{2-}(\mathrm{BE} 166.34 \mathrm{eV} ;$ Abraham and Chaudhri, 1986) (Fig. 5c).

\section{Raman spectroscopy}

The Raman spectra of S-rich and regular monazite-(Ce) is shown in Fig. 6. Band assignments of monazite-(Ce) have been proposed previously by Begun et al. (1981), Silva et al. (2006) and Lenz et al. (2015). Tentative assignments of major Raman bands can be grouped into three different regions: $900-1100 \mathrm{~cm}^{-1}$ are attributable to the stretching of the $\mathrm{PO}_{4}$ tetrahedron; $450-700 \mathrm{~cm}^{-1}$ originate from bending vibrations within the $\mathrm{PO}_{4}$ group; and $<450 \mathrm{~cm}^{-1}$ are related to lattice modes (Supplementary Table S3). No OH stretches were detected above $2900 \mathrm{~cm}^{-1}$ in the Raman spectra of the samples. However, the $633 \mathrm{~nm}$ laser 

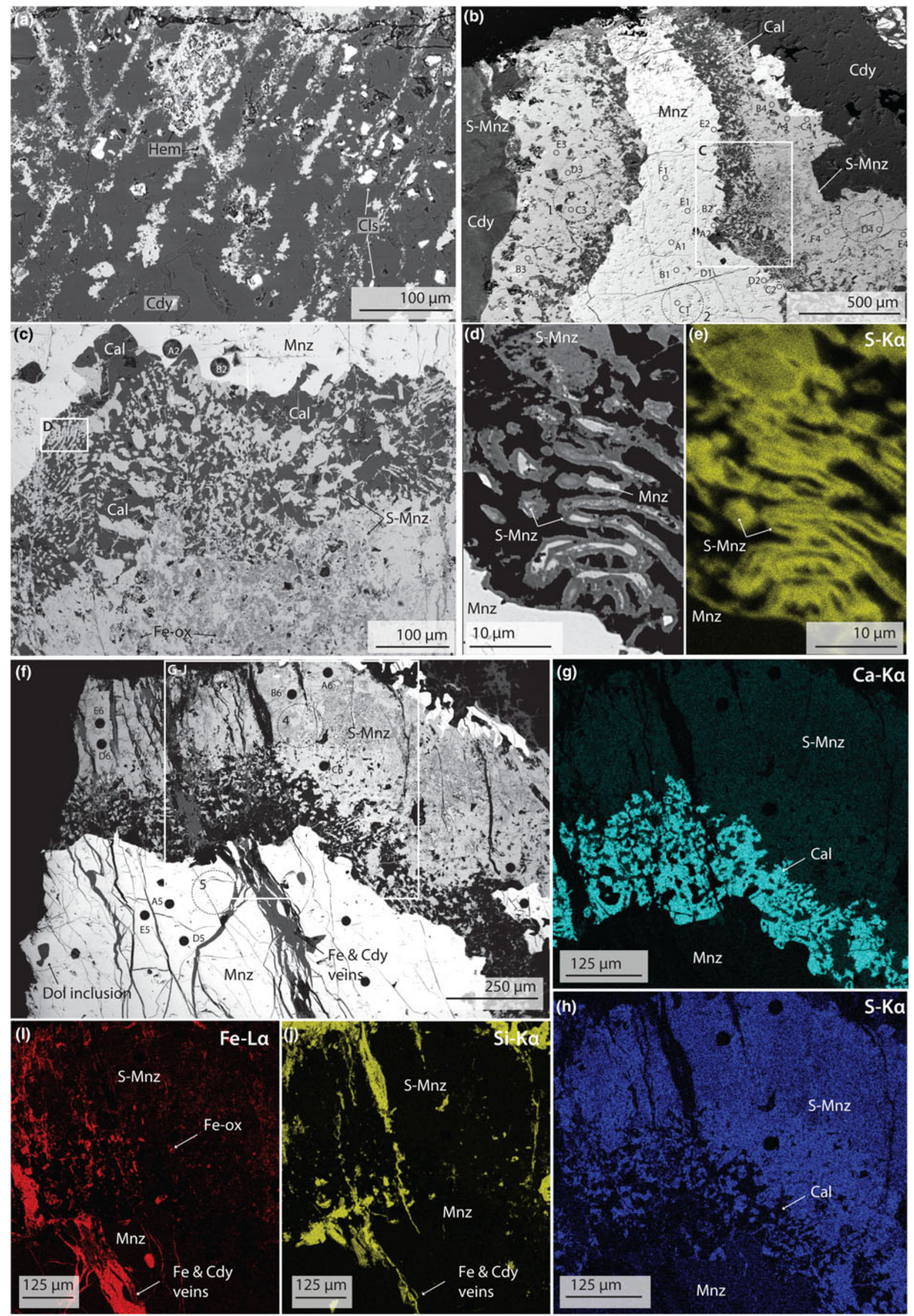
Fig. 3. BSE images $(a-d, f)$ and EDS maps $(e, g-j)$ of silicified carbonatite and monazite-(Ce) from Eureka. (a) Planes of hematite (Hem), intersecting at $\sim 120^{\circ}$, cemented by chalcedony (Cdy) and local, anhdedral, celestite (Cls) grains. (b) Monazite-(Ce) (Mnz) with a large S-bearing monazite-(Ce) rim (S-Mnz), hosted in chalcedony. (c) Close-up of monazite-(Ce)/S-bearing monazite-(Ce) boundary, showing symplectic texture between calcite (Cal) and S-bearing monazite-(Ce). (d) Close-up of monazite and S-bearing monazite rods, showing pore formation at the monazite-(Ce)/S-bearing monazite-(Ce) boundary, with (e) showing changes in the S content of the S-bearing monazite over a small area. $(f)$ Example of cross-cutting chalcedony and hematite veins, through monazite-(Ce) and S-bearing monazite-(Ce). ( $g-j)$ EDS maps demonstrating heterogeneous distribution of $\mathrm{Ca}$ and $\mathrm{S}$ in the S-bearing monazite $(g-h)$, the presence of Ca $(g)$ and Fe (i) inclusions in the S-bearing monazite assemblage, and the presence of chalcedony and hematite veins. Larger circles correspond to sites of XPS analysis, while smaller circles are areas of LA-ICPMS analysis. Numbering corresponds to analytical locations and data in Tables 2, S2, and Fig. 5.

excites an emission of $\mathrm{Nd}^{3+}(4 \mathrm{f} 5 / 2 \rightarrow 419 / 2$ transition $)$, which corresponds to bands in the range $3000-3600 \mathrm{~cm}^{-1}$.

The Raman spectra of S-rich and regular monazite-(Ce) are broadly analogous, but it is possible to observe some differences. In particular, between 900 and $1100 \mathrm{~cm}^{-1}$, there is an intense, sharp band at $968 \mathrm{~cm}^{-1}$, related to symmetric stretching, which has a shoulder at $991 \mathrm{~cm}^{-1}$ and a small band at $1056 \mathrm{~cm}^{-1}$, related to antisymmetric stretching for regular monazite-(Ce). In contrast the bands at 968,991 and $1056 \mathrm{~cm}^{-1}$ are broadened significantly and shifted to 973,1009 and $1074 \mathrm{~cm}^{-1}$ for S-rich monazite-(Ce) (Fig. 6b).

\section{Discussion}

\section{Substitution of minor elements into monazite-(Ce)}

Monazite-(Ce) is monoclinic (space group $\mathrm{P} 2{ }_{1} / \mathrm{n}$ ), comprising equal ratios of $\mathrm{PO}_{4}$ tetrahedra and $R E E \mathrm{O}_{9}$ polyhedra (Ni et al., 1995). The monazite-(Ce) structure differs from the tetragonal $R E E$ phosphate, xenotime-(Y), by a $2.2 \AA$ offset along the [010] plane, allowing space for the larger $L R E E$ atoms, and leading to an additional $R E E-\mathrm{O}$ bond compared with the 8 -fold $R E E O$ site in xenotime ( $\mathrm{Ni}$ et al., 1995). In contrast to xenotime-(Y), the composition of monazite-(Ce) varies considerably in natural

Table 1. Representative compositions of monazite-(Ce) and S-bearing monazite-(Ce) from Eureka (Sample SoS_63c). ${ }^{\star}$

\begin{tabular}{|c|c|c|c|c|c|c|c|c|c|c|c|c|}
\hline \multirow[b]{2}{*}{ Analysis no. } & \multicolumn{6}{|c|}{ S-bearing monazite-(Ce) } & \multicolumn{6}{|c|}{ Monazite-(Ce) } \\
\hline & 1 & 13 & 24 & $\begin{array}{c}\text { Average } \\
n=37\end{array}$ & Max & Min & 38 & 47 & 57 & $\begin{array}{c}\text { Average } \\
n=30\end{array}$ & Max & Min \\
\hline \multicolumn{13}{|l|}{ Wt.\% } \\
\hline $\mathrm{SO}_{3}$ & 10.74 & 10.25 & 8.98 & 9.55 & 11.23 & 7.42 & & & & & & \\
\hline $\mathrm{P}_{2} \mathrm{O}_{5}$ & 22.88 & 22.69 & 23.60 & 23.04 & 24.09 & 22.45 & 31.37 & 31.27 & 30.59 & 31.14 & 31.78 & 30.35 \\
\hline $\mathrm{SiO}_{2}$ & 0.22 & 0.17 & 0.31 & 0.23 & 0.45 & 0.16 & 0.17 & 0.13 & 0.50 & 0.34 & 0.61 & 0.05 \\
\hline $\mathrm{ThO}_{2}$ & 0.67 & 0.51 & 0.69 & 0.54 & 0.71 & 0.36 & 0.59 & 0.65 & 0.61 & 0.62 & 0.75 & 0.43 \\
\hline $\mathrm{La}_{2} \mathrm{O}_{3}$ & 10.92 & 10.80 & 11.04 & 10.82 & 11.83 & 9.49 & 25.99 & 22.88 & 29.29 & 26.62 & 32.76 & 22.61 \\
\hline $\mathrm{Ce}_{2} \mathrm{O}_{3}$ & 28.91 & 28.37 & 28.95 & 29.19 & 30.63 & 27.40 & 32.47 & 33.24 & 31.60 & 32.76 & 33.70 & 30.74 \\
\hline $\mathrm{Pr}_{2} \mathrm{O}_{3}$ & 2.96 & 2.90 & 2.33 & 2.75 & 3.13 & 2.30 & 2.63 & 2.75 & 2.06 & 2.22 & 2.90 & 1.01 \\
\hline $\mathrm{Nd}_{2} \mathrm{O}_{3}$ & 10.44 & 10.25 & 10.90 & 10.62 & 11.45 & 9.78 & 8.19 & 10.02 & 6.31 & 7.72 & 10.02 & 4.95 \\
\hline $\mathrm{Sm}_{2} \mathrm{O}_{3}$ & 0.52 & 0.54 & 0.56 & 0.63 & 0.75 & 0.51 & & 0.32 & & 0.26 & 0.33 & \\
\hline $\mathrm{Gd}_{2} \mathrm{O}_{3}$ & 0.22 & 0.20 & 0.21 & 0.23 & 0.32 & 0.15 & & 0.19 & & 0.18 & 0.19 & \\
\hline $\mathrm{CaO}$ & 6.71 & 6.78 & 6.67 & 6.60 & 7.18 & 5.81 & 0.06 & 0.11 & 0.13 & 0.07 & 0.13 & \\
\hline $\mathrm{FeO}$ & & 1.51 & 0.49 & 1.02 & 2.21 & & & & 0.10 & 0.10 & 0.10 & \\
\hline SrO & 4.64 & 4.46 & 4.20 & 4.03 & 5.72 & 2.90 & 0.15 & 0.26 & 0.10 & 0.16 & 0.28 & \\
\hline $\mathrm{Na}_{2} \mathrm{O}$ & 0.24 & 0.20 & 0.21 & 0.23 & 0.32 & 0.12 & & & & & & \\
\hline $\mathrm{F}^{2}$ & 0.87 & 0.73 & 0.73 & 0.82 & 1.09 & 0.64 & & & & & & \\
\hline Total & 100.94 & 100.37 & 99.86 & 100.17 & 101.80 & 98.48 & 101.62 & 101.81 & 101.30 & 101.63 & 102.22 & 100.81 \\
\hline Total $(-\mathrm{O} \equiv \mathrm{F})$ & 100.58 & 100.06 & 99.55 & 99.82 & 101.51 & 98.10 & & & & & & \\
\hline \multicolumn{13}{|c|}{ Atoms per formula unit calculated to 40} \\
\hline$S^{6+}$ & 0.286 & 0.275 & 0.244 & & & & & & & & & \\
\hline$P^{5+}$ & 0.686 & 0.686 & 0.722 & & & & 1.010 & 1.008 & 0.992 & & & \\
\hline $\mathrm{Si}^{4+}$ & 0.008 & 0.006 & 0.011 & & & & 0.006 & 0.005 & 0.019 & & & \\
\hline $\mathrm{Th}^{4+}$ & 0.005 & 0.004 & 0.006 & & & & 0.005 & 0.006 & 0.005 & & & \\
\hline $\mathrm{La}^{3+}$ & 0.143 & 0.142 & 0.147 & & & & 0.365 & 0.321 & 0.414 & & & \\
\hline $\mathrm{Ce}^{3+}$ & 0.375 & 0.371 & 0.383 & & & & 0.452 & 0.463 & 0.443 & & & \\
\hline $\mathrm{Pr}^{3+}$ & 0.038 & 0.038 & 0.031 & & & & 0.036 & 0.038 & 0.029 & & & \\
\hline $\mathrm{Nd}^{3+}$ & 0.132 & 0.131 & 0.141 & & & & 0.111 & 0.136 & 0.086 & & & \\
\hline $\mathrm{Sm}^{3+}$ & 0.006 & 0.007 & 0.007 & & & & & 0.004 & & & & \\
\hline $\mathrm{Gd}^{3+}$ & 0.003 & 0.002 & 0.003 & & & & & 0.002 & & & & \\
\hline $\mathrm{Ca}^{2+}$ & 0.255 & 0.260 & 0.258 & & & & 0.003 & 0.004 & 0.005 & & & \\
\hline $\mathrm{Fe}^{2+}$ & & 0.045 & 0.015 & & & & & & 0.003 & & & \\
\hline $\mathrm{Sr}^{2+}$ & 0.095 & 0.092 & 0.088 & & & & 0.003 & 0.006 & 0.002 & & & \\
\hline $\mathrm{Na}^{+}$ & 0.009 & 0.008 & 0.008 & & & & & & & & & \\
\hline $\mathrm{F}^{-}$ & 0.046 & 0.039 & 0.038 & & & & & & & & & \\
\hline REE site & 1.062 & 1.100 & 1.085 & & & & 0.975 & 0.982 & 0.989 & & & \\
\hline $\mathrm{PO}_{4}$ site & 0.980 & 0.968 & 0.977 & & & & 1.016 & 1.013 & 1.012 & & & \\
\hline
\end{tabular}

*Blank cells denote analyses below the EPMA detection limit; Y, Dy and U are below detection in all samples, Ba below detection in all but 2 S-bearing samples. Full dataset in Supplementary Table S1. 


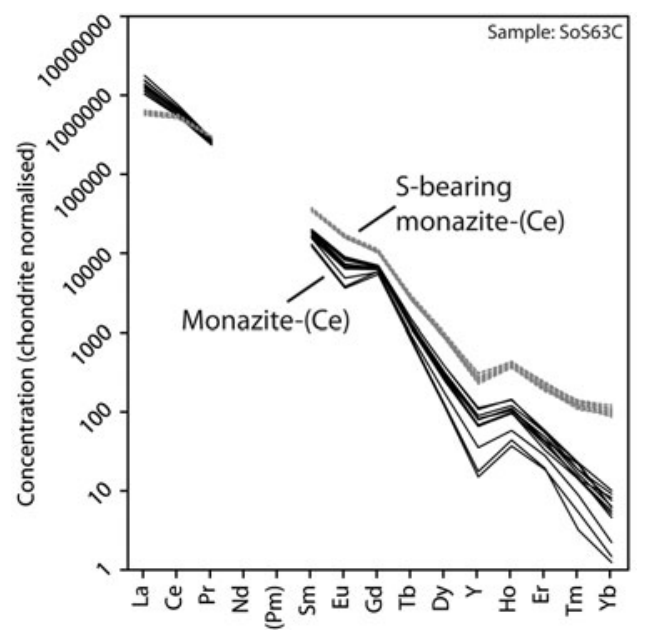

Fig. 4. Chondrite-normalised REE distribution of monazite-(Ce) and S-bearing monazite-(Ce) from Eureka. Chondrite values after McDonough and Sun (1995).

samples (e.g. Förster, 1998), which might be a consequence of the irregular REE-O bond distances from the 9-fold coordination (Beall et al., 1981). In addition to isomorphous $R E E^{3+}$ substitution, the 9 fold site also commonly accommodates other large cations, such as $\mathrm{Th}^{4+}, \mathrm{U}^{4+}$ and $\mathrm{M}^{2+}$ (e.g. $\mathrm{Ca}^{2+}, \mathrm{Sr}^{2+}, \mathrm{Pb}^{2+}, \mathrm{Ba}^{2+}$ ) with charge-balance achieved typically by the cheralite or huttonite substitution:

$$
\text { Cheralite substitution: } 2 \mathrm{Ce}^{3+} \leftrightarrow \mathrm{Th}^{4+}+\mathrm{Ca}^{2+}
$$

Huttonite substitution: $\mathrm{P}^{5+}+R E E^{3+} \leftrightarrow \mathrm{Si}^{4+}+\mathrm{Th}^{4+}$

The above two mechanisms account for the incorporation of minor elements in monazite-(Ce) grains (without $S$ ) at Eureka. The similar number of $\mathrm{Th}^{4+}$ and $\mathrm{Ca}^{2+}+\mathrm{Sr}^{2+}+\mathrm{Fe}^{2+}$ apfu suggests that cheralite substitution predominantly accommodates the Th in this phase, with a minor huttonite component. A minor huttonite component can also predominantly account for $\mathrm{Th}^{4+}$ in the S-bearing monazite-(Ce), as the number of $\mathrm{Si}^{4+}$ apfu is equal, or greater than the $\mathrm{Th}^{4+}$ apfu in this phase.

Sulfur substitution in monazite-(Ce) is relatively uncommon and, consequently, relatively understudied. Early work by Kukharenko et al. (1961) suggested that S substitutes into the tetragonal $\mathrm{PO}_{4}$ site via a coupled substitution with anhydrite (also termed 'clino-anhydrite' and 'anhydrite-celestite' exchange by subsequent workers), based on a positive correlation between $\mathrm{S}$ and $\mathrm{Ca}+\mathrm{Sr}$ cations:

$$
(\mathrm{Sr}, \mathrm{Ca})^{2+}+\mathrm{S}^{6+} \leftrightarrow R E E^{3+}+\mathrm{P}^{5+}
$$

An isomorphous substitution with $\mathrm{Si}$ has also been suggested (Williams et al., 2007):

$$
\mathrm{S}^{6+}+\mathrm{Si}^{4+} \leftrightarrow 2 \mathrm{P}^{5+}
$$

Narrow XPS scans of the $S$ peaks clearly demonstrate that sulfur is predominantly incorporated in monazite-(Ce) as sulfate $($ Fig. $5 b-c)$. A positive correlation between $\mathrm{Sr}+\mathrm{Ca}$ and $\mathrm{S}$ in the S-bearing monazite-(Ce) at Eureka is a strong indication that clino-anhydrite exchange (Fig. 7) accounts for the $\mathrm{S}$ content in this example, while low $\mathrm{Si}$ and Th contents suggest substitutions involving these elements do not play a role (Chakhmouradian and Mitchell, 1999; Bulakh et al., 2000; Wall, 2004; Ondrejka et al., 2007, 2016; Pršek et al., 2010; Krenn et al., 2011; Laurent et al., 2016). The capability of anhydrite to exist in the monoclinic crystal system, albeit at high pressures, gives credence to the possibility of clino-anhydrite substitution (Kahn, 1975; Borg and Smith, 1975; Crichton et al., 2005; Bradbury and Williams, 2009). However, clino-anhydrite exchange cannot be the sole mechanism for the incorporation of sulfate, as it results invariably in an excess of $M^{2+}$ cations (Fig. 7a). This excess is not accommodated by cheralite substitution as there is insufficient $\mathrm{Th}^{4+}$ to balance the $\mathrm{M}^{2+}$ excess (Fig. 7b). To accommodate this imbalance, Chakhmouradian and Mitchell (1999) suggested the presence of an auxiliary substitution mechanism:

$$
R E E^{3+}+\mathrm{O}^{2-} \leftrightarrow(\mathrm{Ca}, \mathrm{Sr})^{2+}+\mathrm{OH}^{-}
$$

The absence of an $\mathrm{OH}$ peak in Raman data for the S-bearing monazite-(Ce) from Eureka (Fig. 6), however, means the above charge-balancing substitution is not a viable mechanism to accommodate the $M^{2+}$ excess. Moreover, our analytical totals from EPMA are within uncertainty of $100 \%$ (Table 1), rather than $<100 \%$ as might be expected if $\mathrm{OH}$ substitution is taking place. We, therefore, propose that $\mathrm{OH}$ does not accommodate the $M^{2+}$ excess and, instead, we suggest an alternative auxiliary substitution where excess $M^{2+}$ cations are countered by F substituting for oxygen:

$$
R E E^{3+}+\mathrm{O}^{2-} \leftrightarrow(\mathrm{Ca}, \mathrm{Sr})^{2+}+\mathrm{F}^{-}
$$

The additional charge-balancing of $\mathrm{F}$ considerably, although not entirely, reduces the $M^{2+}$ excess (Fig. 7c). The F content of monazite-(Ce) is not commonly analysed, but $\mathrm{F}$ concentrations up to 0.8 wt.\% have been reported from Steenkampskraal monazite-(Ce) (Andreoli et al., 1994). Moreover, F has been suggested to account for small excesses in $\mathrm{Si}$ after cheralite- and huttonite-type substitutions have been accounted for (Williams et al., 2007). Few data are available where both $\mathrm{SO}_{3}$ and $\mathrm{F}$ contents are reported and above the EPMA limit of detection, although monazite-(Ce) from the Tomtor, Khaluta and Huanglongpu carbonatites, and the Tisovec-Rejkovo rhyolite, are notable exceptions (Doroshkevich et al., 2001; Ondrejka et al., 2007; Lazareva et al., 2015; Chen et al., 2017). In these instances, however, the proportion of $\mathrm{Ca}+\mathrm{Sr}$ and $\mathrm{S}+\mathrm{F}$ are not balanced, indicating that other mechanisms, such as co-substitution with $\mathrm{SiO}_{3}^{2-}$ may be accommodating F (Williams et al., 2007). Nonetheless, in the absence of a better explanation to accommodate the $\mathrm{M}^{2+}$ excess, we place considerable weight onto an auxiliary $\mathrm{F}$ substitution mechanism to accommodate charge imbalance.

\section{Structural distortion in S-bearing monazite-(Ce)}

The XPS binding energy spectra show that sulfur is present predominantly in S-bearing monazite-(Ce) as sulfate, as expected from the correlation between $\mathrm{S}$ and $\mathrm{Ca}+\mathrm{Sr}$ contents. However, the X-ray photoelectron spectra also exhibits a minor additional peak for sulfide $\left(\mathrm{S}^{2-}\right)$, and peak deconvolution indicates a small overlap with sulfite $\left(\mathrm{S}^{4+}\right.$; Fig. $\left.5 c\right)$. Tests on iron sulfate show that sulfur does not undergo redox reaction under the $\mathrm{Ar}^{+}$ beam, and these peaks are significantly above background, so do not represent artefacts. The possibility of contamination of sulfite and sulfide from other phases is also unlikely as no other 


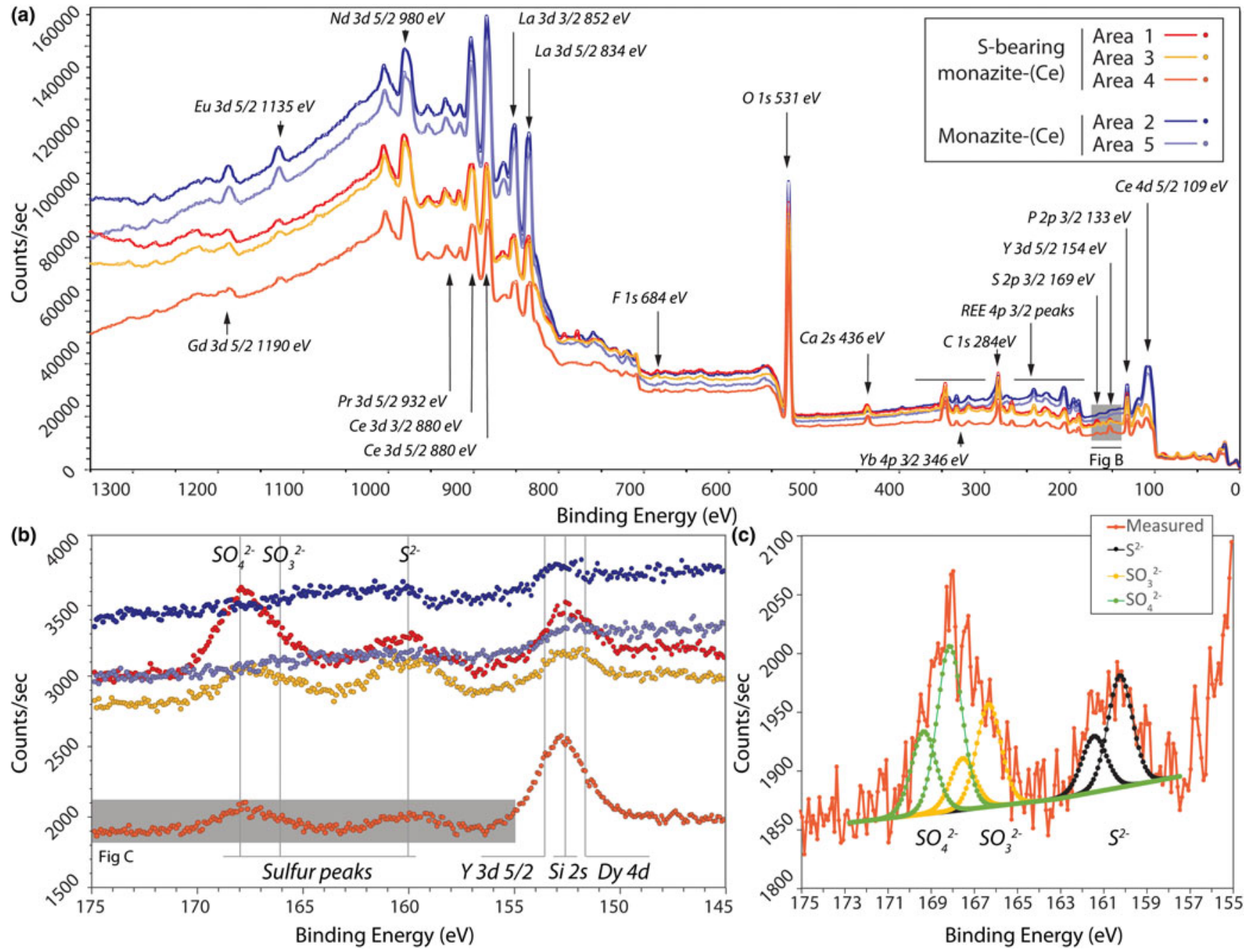

Fig. 5. (a) X-ray photoelectron binding energy spectra of monazite-(Ce) from sites shown in Fig. 3. Note the HREE, S and Ca peaks present in the S-bearing monazite-(Ce). (b) Narrow scan of the Dy, Si, Y and S peaks. (c) Narrow scan of the S $2 p$ binding energy peak indicating sulfur present as sulfite, sulfate and sulfide structurally bound in monazite-(Ce). Binding-energy peak positions from ThermoScientific, xpssimplified.com (accessed 2017), NIST XPS database (accessed 2017), Yu et al., (1990), Vasquez (1991) and Abraham and Chaudhri (1986).

S-bearing phases are present in association with the S-bearing monazite-(Ce) (Fig. $3 e, h$ ). We cannot discount entirely the possibility that such phases may be present as nano-inclusions (e.g. Laurent et al., 2016). However, ${ }^{32} \mathrm{~S}$ and ${ }^{56} \mathrm{Fe}$ contents from LA-ICPMS analyses shows no clear correlation, indicating that pyrite is not present in the analyses (Supplementary Fig. S2; Fig. $3 i-j)$.

Accommodating sulfur in monazite-(Ce) in oxidation states other than $\mathrm{S}^{6+}$ is somewhat challenging. In terms of chargebalance, $\mathrm{S}^{4+}$ could replace the $\mathrm{Si}^{4+}$ component in a pseudohuttonite substitution, or as a coupled substitution with $\mathrm{P}^{5+}$ :

$$
\begin{gathered}
\mathrm{S}^{4+}+\mathrm{Th}^{4+} \leftrightarrow \mathrm{P}^{5+}+R E E^{3+} \\
\mathrm{S}^{6+}+\mathrm{S}^{4+} \leftrightarrow 2 \mathrm{P}^{5+}
\end{gathered}
$$

The former option can be ruled out in this instance as $\mathrm{Th}^{4+}$ contents are very low, and can be accommodated by huttonite substitution. For sulfide, direct $\mathrm{S}^{2-}$ for $\mathrm{O}^{2-}$ may accommodate $\mathrm{S}^{2-}$ :

$$
\mathrm{S}^{2-} \leftrightarrow \mathrm{O}^{2-}
$$

Recent micro X-ray absorption near-edge structure analyses of both laboratory-synthesised and natural samples have indicated that sulfide and sulfite can occur in apatite (Konecke et al., 2017a, 2017b; Brounce et al., 2019; Sadove et al., 2019), which helps to support the concept that these species may occur in monazite-(Ce) as well. Ab initio studies of apatite support the mechanism for coupled substitution of $S^{6+}$ and $S^{4+}$ for $\mathrm{P}^{5+}$ (Kim et al., 2017). Sulfite occurs as a trigonal pyramid with a lone electron pair replacing one of the $\mathrm{O}$ atoms in the substituted $\mathrm{PO}_{4}$ (or $\mathrm{SO}_{4}$ ). The stability of sulfite substitution in apatite is affected by the presence of the anion column, which repels the lone pair of electrons in the sulfite trigonal pyramid. The highest stability occurs in chlorapatite owing to increased distance between the $\mathrm{Cl}^{-}$anion and the electron pair, relative to $\mathrm{OH}^{-}$ and $\mathrm{F}^{-}$(Kim et al., 2017). The absence of the anion column in monazite-group minerals therefore suggests that sulfite substitution may be more stable than in apatite. Conversely, however, $\mathrm{S}^{2-}$ is accommodated in the anion site in apatite (Kim et al., 2017), and no such site is available in monazite- $(\mathrm{Ce})$. Substituting $\mathrm{S}^{2-}$ for $\mathrm{O}^{2-}$ is difficult to reconcile with the monazite-(Ce) structure owing to the considerable size difference between these two 


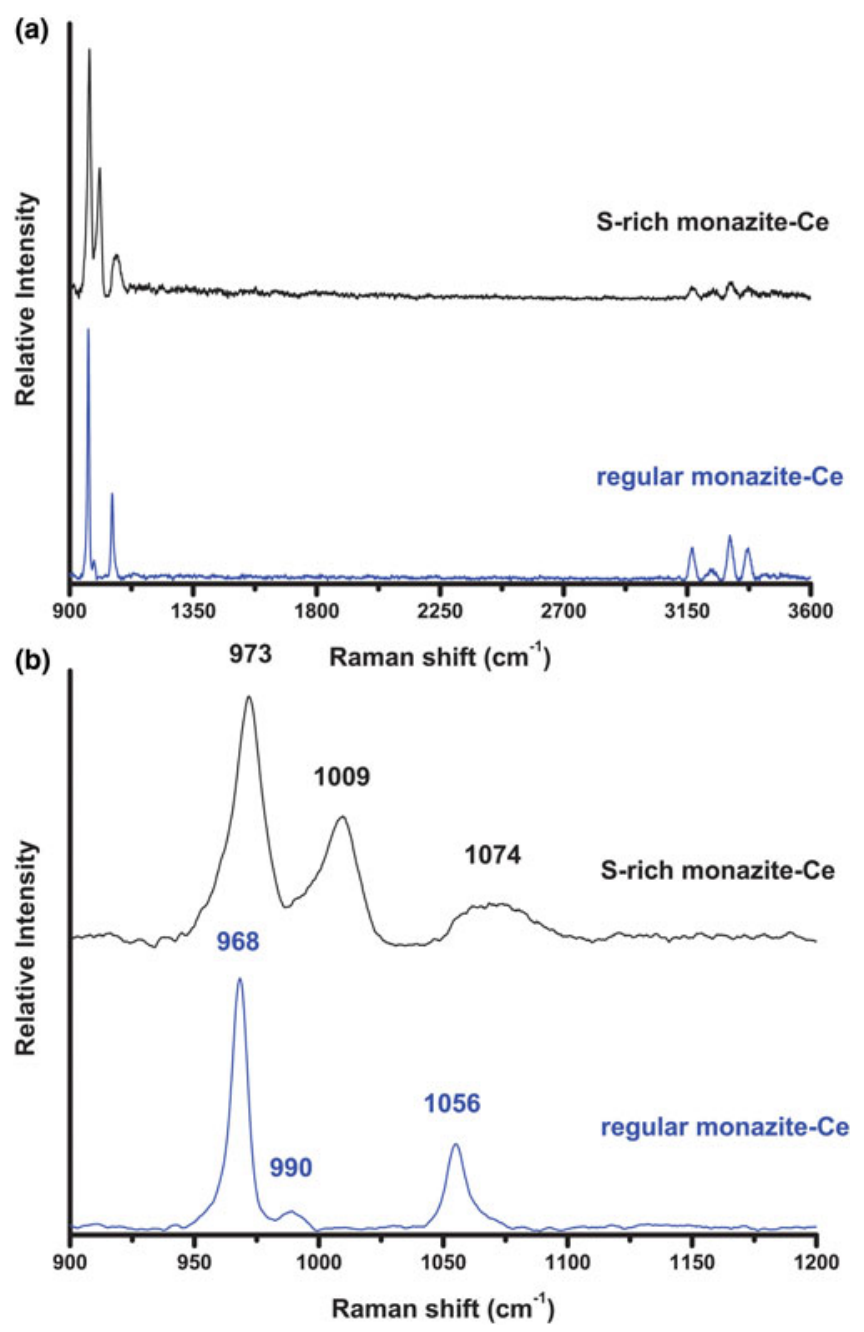

Fig. 6. (a) Raman spectra of monazite-(Ce) and S-bearing monazite-(Ce) from sample SoS_63c. (b) Enlarged version of the above, demonstrating peak broadening and shifting.

anions. All three of the above substitutional mechanisms would result in mis-matched geometry, and would probably result in local defects and structural distortion. Moreover, these mechanisms also exacerbate the problem of $M^{2+}$ excess, as the chargebalancing contribution of $S$ is reduced.

While we lack evidence to support conclusively the three substitution mechanisms suggested above, stretches in the Raman bands at 968, 991 and $1056 \mathrm{~cm}^{-1}$ do indicate changes in the $\mathrm{P}-\mathrm{O}$ bond distance caused by structural distortion (Fig. 6). The sulfate ion is $\sim 70 \%$ of the size of the phosphate ion (Shannon, 1976), suggesting the unit cell of monazite-(Ce) contracts as a result of increasing degrees of exchange with clino-anhydrite, which could potentially accommodate larger ions to compensate. Such a contraction is supported by the data of Bulakh et al. (2000) who demonstrated that the unit cell volume of monazite-(Ce) with $\sim 3 \% \mathrm{SO}_{3}$ is $\sim 2 \%$ lower than that of monazite-(Ce) with no $\mathrm{S}$ substitution. The smaller size of the sulfate ion, in comparison with the substituted phosphate, may also help explain the slightly elevated Mo and $\mathrm{V}$ contents, as both molybdate and vanadate ions form substantially larger tetrahedra than $\mathrm{PO}_{4}$. Ondrejka et al. (2007) noted elevated $\mathrm{SO}_{3}$ contents in As-bearing monazite-(Ce)/ gasparite-(Ce) which, owing to the similar size of the arsenate,
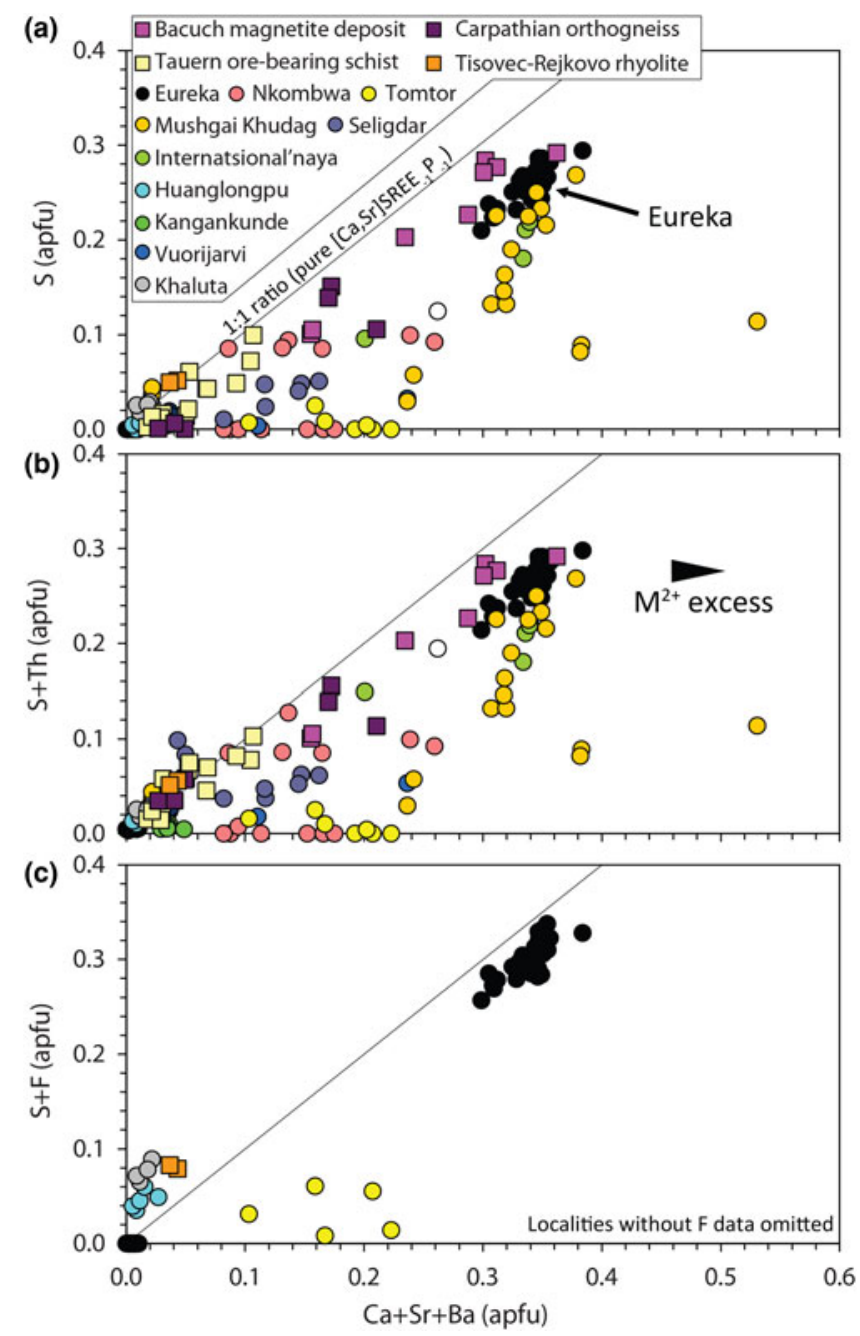

Fig. 7. Composition of monazite-(Ce) from Eureka compared with data compiled from other carbonatite complexes (circles; Kukharenko et al., 1961; Cressey et al., 1999; Bulakh et al., 2000; Doroshkevich et al., 2001; Wall, 2004; Lazareva et al., 2015; Enkhbayar et al., 2016; Prokopyev et al., 2017; Nikolenko et al., 2018), the Internatsional'naya kimberlite (Chakhmouradian and Mitchell, 1999), and other published occurrences (squares) with $\mathrm{SO}_{3}>1 \%$ (Ondrejka et al., 2007; Pršek et al., 2010; Krenn et al., 2011; Ondrejka et al., 2016).

molybdate and vanadate ions, may be analogous. Similarly, we suggest that the slightly elevated contents of HREE and $\mathrm{Zr}$ are a consequence of this structural distortion, rather than reflecting any significant change in the formation environment or $R E E$ fractionation during transport.

\section{Crystallisation environment of S-bearing monazite-(Ce) at Eureka}

Sulfur-bearing monazite-(Ce) is relatively rare in carbonatites although this may, in-part, result from $S$ not being included routinely in a monazite-(Ce) EPMA routine. A compilation of monazite-(Ce) compositions from different carbonatites was presented by Chen et al. (2017). The majority of these data have $<1 \%$ $\mathrm{SO}_{3}$, in addition, published occurrences with monazite-(Ce) containing $>1 \% \mathrm{SO}_{3}$ are limited to Nkombwa, Zambia (Wall, 2004); Vuoriyarvi and Seligdar, Russia (Kukharenko et al., 1961; Bulakh, 2000; Prokopyev et al., 2017); and Mushgai Khudag, Mongolia (Enkhbayar et al., 2016; Nikolenko et al., 2018). In all of these 
Table 2. Representative trace-element data (in $\mu \mathrm{g} / \mathrm{g}$ ) of monazite-(Ce) and S-bearing monazite-(Ce) from Eureka (Sample SoS_63c). ${ }^{*}$

\begin{tabular}{|c|c|c|c|c|c|c|c|c|c|c|c|c|}
\hline & \multicolumn{6}{|c|}{ S-bearing monazite-(Ce) } & \multicolumn{6}{|c|}{ Monazite-(Ce) } \\
\hline & A3 & D4 & B6 & Average (19) & Max & Min & $\mathrm{A} 1$ & D2 & A5 & Average (13) & Max & Min \\
\hline${ }^{23} \mathrm{Na}$ & 1463 & 2017 & 1940 & 1487 & 2017 & 1068 & & 39 & & 31 & 39 & 22 \\
\hline${ }^{28} \mathrm{Si}$ & 2590 & 2010 & 1910 & 2174 & 2990 & 1720 & 720 & 2190 & 1340 & 2423 & 5670 & 590 \\
\hline${ }^{31} \mathrm{P}$ & 17,000 & 15,230 & 17,600 & 16,859 & 18,800 & 15,100 & 22,900 & 24,800 & 31,100 & 26,815 & 32,600 & 22,900 \\
\hline${ }^{32} \mathrm{~S}$ & 89,800 & 70,400 & 73,700 & 87,758 & 110,000 & 63,500 & 1780 & 1600 & & 1918 & 2740 & 1330 \\
\hline${ }^{40} \mathrm{Ca}$ & 69,500 & 46,200 & 44,800 & 57,753 & 69,500 & 44,800 & 515 & 898 & 636 & 650 & 1170 & 378 \\
\hline${ }^{47} \mathrm{Ti}$ & & 112 & & 49 & 112 & 22 & & & & & & \\
\hline${ }^{51} \mathrm{~V}$ & 72.2 & 38.2 & 41.8 & 81 & 207 & 38 & & 6.9 & & 6 & 10 & \\
\hline${ }^{56} \mathrm{Fe}^{\star \star}$ & 8600 & 17820 & 15910 & 15,990 & 44,400 & 534 & & 60.5 & 1.2 & 174 & 1022 & \\
\hline${ }^{88} \mathrm{Sr}$ & 47,800 & 33,600 & 29,400 & 43,914 & 56,700 & 27,060 & 1673 & 2240 & 1873 & 1538 & 2244 & 312 \\
\hline${ }^{89} \mathrm{Y}$ & 400 & 482 & 477 & 420 & 494 & 353 & 170 & 177.6 & 103.5 & 110 & 178 & 24 \\
\hline${ }^{90} \mathrm{Zr}$ & 21.6 & 32.9 & 33.4 & 22 & 33 & 12 & 0.48 & 0.8 & & 0.65 & 1.02 & \\
\hline${ }^{93} \mathrm{Nb}$ & 3.9 & 52.3 & 13.5 & 11 & 52 & 1 & & 1.55 & & 1.60 & 3.40 & \\
\hline${ }^{95} \mathrm{Mo}$ & 45 & 18.7 & 24 & 54 & 142 & 19 & & & & & & \\
\hline${ }^{137} \mathrm{Ba}$ & 171 & 112.4 & 105 & 150 & 231 & 102 & 5.9 & 10.1 & 6.9 & 7 & 13 & 1 \\
\hline${ }^{139} \mathrm{La}$ & 151,300 & 149,900 & 142,900 & 144,737 & 154,500 & 133,100 & 246,400 & 274,000 & 330,400 & 311,300 & 421,000 & 246,400 \\
\hline${ }^{140} \mathrm{Ce}$ & 347,600 & 344,800 & 338,000 & 335,737 & 353,000 & 311,900 & 336,500 & 352,000 & 409,000 & 385,538 & 462,000 & 335,800 \\
\hline${ }^{141} \mathrm{Pr}$ & 27,910 & 27,100 & 27,140 & 27,381 & 28,280 & 26,730 & 21,890 & 22,750 & 24,690 & 23,906 & 26,000 & 21,890 \\
\hline${ }^{147} \mathrm{Sm}$ & 5130 & 5450 & 5590 & 5203 & 5590 & 4970 & 2977 & 2912 & 2344 & 2512 & 2977 & 1821 \\
\hline${ }^{153} \mathrm{Eu}$ & 900 & 969 & 981 & 909 & 981 & 871 & 509 & 485 & 359 & 373 & 509 & 204 \\
\hline${ }^{157} \mathrm{Gd}$ & 2090 & 2198 & 2247 & 2081 & 2247 & 1968 & 1394 & 1374 & 1246 & 1268 & 1394 & 1075 \\
\hline${ }^{159} \mathrm{~Tb}$ & 94.7 & 105.3 & 105.1 & 96 & 105 & 89 & 52.2 & 52.1 & 40.5 & 41 & 52 & 28 \\
\hline${ }^{163}$ Dy & 219.5 & 245 & 239.7 & 220 & 245 & 206 & 92.5 & 92 & 60.9 & 65 & 93 & 28 \\
\hline${ }^{165} \mathrm{Ho}$ & 20.48 & 24.1 & 24.09 & 21 & 24 & 20 & 7.96 & 7.73 & 5.36 & 5.3 & 8.0 & 2.0 \\
\hline${ }^{166} \mathrm{Er}$ & 33 & 36 & 36.8 & 33 & 38 & 29 & 8.72 & 9.41 & 5.28 & 6.5 & 9.4 & 3.0 \\
\hline${ }^{169} \mathrm{~Tb}$ & 3.04 & 3.52 & 3.28 & 3.1 & 3.5 & 2.7 & 0.56 & 0.56 & 0.35 & 0.4 & 0.6 & 0.1 \\
\hline${ }^{172} \mathrm{Yb}$ & 16.5 & 19.4 & 17.9 & 16.3 & 19.4 & 13.9 & 0.99 & 1.64 & 1.33 & 0.9 & 1.6 & 0.2 \\
\hline${ }^{175} \mathrm{Lu}$ & 2.24 & 2.73 & 2.58 & 2.29 & 2.99 & 1.86 & 0.16 & 0.238 & 0.068 & 0.13 & 0.24 & 0.05 \\
\hline${ }^{178} \mathrm{Hf}$ & & 0.29 & 0.101 & 0.12 & 0.29 & & & & & & & \\
\hline${ }^{208} \mathrm{~Pb}$ & 99.1 & 82.8 & 102 & 99 & 126 & 83 & 184.6 & 212 & 194.9 & 199 & 265 & 174 \\
\hline${ }^{232} \mathrm{Th}$ & 6440 & 3930 & 4150 & 5678 & 7470 & 3930 & 5400 & 6120 & 4350 & 5412 & 7930 & 4040 \\
\hline${ }^{238} \mathrm{U}$ & 208.7 & 229 & 233.5 & 211 & 300 & 125 & 144 & 121.5 & 61.3 & 81 & 144 & 26 \\
\hline
\end{tabular}

*Blank cells denote analyses below the LA-ICPMS detection limit. Full dataset in Supplementary Table S2.

${ }^{\star} \star 56 \mathrm{Fe}$ contents $>15,000 \mu \mathrm{g} / \mathrm{g}$ may be contaminated with inclusions of an Fe-oxide mineral.

occurrences, monazite-(Ce) forms at a late stage in the crystallisation history of the carbonatites. Commonly, formation is considered to be related to a hydrothermal process, with temperature estimates from fluid-inclusion data between $385-315^{\circ} \mathrm{C}$ at Seligdar and $150-250^{\circ} \mathrm{C}$ at Mushgai Khudag (Prokopyev et al., 2017; Nikolenko et al., 2018).

There is little evidence for substantial hydrothermal alteration at Eureka. Local alteration includes small-scale quartz veins and carbonate recrystallisation. However, there is no evidence linking these events with the formation of the S-bearing monazite-(Ce). Instead, S-bearing monazite- $(\mathrm{Ce})$ is considered here to be related to carbonatite weathering and duricrust formation. S-bearing monazite-(Ce) is found exclusively in silicified rocks (Fig. 3), which are restricted to $\sim 5 \mathrm{~m}$ depth, and limited commonly to much shallower levels. Duricrusts are prevalent in the Namib Desert, with calcrete common in the area around Eureka (Viles and Goudie, 2013). Localised silcrete can form in calcrete owing to the $\mathrm{pH}$-controlled inverse solubility relationship between silica and calcite, with precipitation of silica favoured when $\mathrm{pH}$ is $<9$, and vice-versa (Watts, 1980). Mixing of Si-rich porefluids with alkaline water leads to $\mathrm{Si}$ precipitation, while Si-rich solutions in the presence of carbonate minerals become unstable in a saline or high $\mathrm{CO}_{2}$ environment (Watts, 1980; Nash and Shaw, 1998). A change in salinity is possible in a continental environment by mixing meteoric water with saline lake fluids, while $\mathrm{CO}_{2}$ can be introduced into groundwater through biological activity or the decomposition of organic matter (Bustillo, 2010). Alternatively, reduction of $\mathrm{pH}$ at oxic/anoxic boundaries, such as the through oxidation of $\mathrm{H}_{2} \mathrm{~S}$, can lead to silica precipitation (Bustillo, 2010). Of these three possibilities, salinity change seems the most probable, owing to the close proximity of the Eureka carbonatites to ephemeral rivers and the salinity of local groundwater (encountered at $\sim 60 \mathrm{~m}$ during drilling). However, when considering the $\mathrm{S}$ source, a contribution from $\mathrm{H}_{2} \mathrm{~S}$ cannot be entirely excluded.

\section{Formation mechanism for S-bearing monazite-(Ce) at Eureka}

While the sole association of the S-bearing monazite-(Ce) with silicified rocks demonstrates that weathering and silicification play a key role in its formation, the exact growth mechanism of the S-bearing monazite-(Ce) is unclear. Solid-state diffusion is unlikely given the lack of a local source of $S$, and negligible diffusion rates in monazite below $800^{\circ} \mathrm{C}$ (Cherniak et al., 2004; Gardés et al., 2006, 2007). Overgrowths can also be excluded owing to the corroded and pitted texture of the core monazite-(Ce) grains (Fig. 3b,c). Instead, we propose that the S-bearing monazite-(Ce) probably formed via a dissolutionprecipitation reaction (Putnis, 2002, 2009). Such a reaction involves fluid-mediated replacement of a phase to reduce the free energy of a system. The product phase(s) must be a lower molar volume or higher solubility in order for the reaction to propagate (Putnis and Ruiz-Agudo, 2013). Although monazite is a relatively insoluble mineral (e.g. Poitrasson et al., 2004; Cetiner et al., 2005), dissolution-precipitation has been demonstrated experimentally across a wide range of pressures and 
temperatures (e.g. Hetherington et al., 2010; Harlov and Hetherington, 2010; Harlov et al., 2011; Budzyń et al., 2016). Texturally, the S-bearing monazite-(Ce) fits several characteristics of a dissolution-precipitation reaction (Putnis, 2002, 2009), such as: (1) the close relationship between the parent and product phases; (2) a sharp reaction front between these two phases; and (3) development of porosity and permeability in the product phase (Fig. $3 d$ ). Fractures also occur perpendicular to the reaction front (e.g. Fig. $3 f$ ), although these are localised and cross-cut the product phase, suggesting formation unrelated to the growth of S-bearing monazite-(Ce).

Although the textural evidence for a dissolution-precipitation formation mechanism is convincing, we note that no experimental work has yet demonstrated that such a process occurs under ambient conditions similar to those suggested to form the S-bearing monazite-(Ce) at Eureka. Indeed, the lowesttemperature dissolution-precipitation experiments on monazite(Ce) demonstrate quite contrasting findings. Grand'Homme et al. (2018) showed that a relatively simple assemblage of monazite, quartz, $\mathrm{H}_{2} \mathrm{O}$ and $\mathrm{NaOH}$ dissolved at $300^{\circ} \mathrm{C}$, but secondary monazite did not form. In contrast, Budzyń et al. (2015) found monazite does show dissolution and precipitation textures in an experiment at $250^{\circ} \mathrm{C}$ with a similar, but more complex, assemblage of monazite, $\mathrm{K}$-feldspar, albite, muscovite, biotite, $\mathrm{H}_{2} \mathrm{O}$ and $\mathrm{Na}_{2} \mathrm{Si}_{2} \mathrm{O}_{5}$. At crystallisation temperatures below those of the above experiments, the more common $L R E E$ phosphate occurring in nature is the hydrated equivalent to monazite-(Ce), rhabdophane-(Ce) (Kolitsch and Holtstam, 2004). Nonetheless, rare occurrences of monazite-(Ce) in diagenetic, weathering and low-grade metamorphic environments have been described (e.g. Cooper et al., 1983; Oliveira and Imbernon, 1998; Cabella et al., 2001; Rasmussen and Muhling, 2007; Čopjaková et al., 2011), indicating that monazite can form in such environments at low temperatures. It is not clear, however, why S-bearing monazite at Eureka is a more stable assemblage under such conditions, rather than a mixture of gypsum and monazite-(Ce).

Cross-cutting relationships indicate that chalcedony continued to form after the cessation of S-bearing monazite-(Ce) growth. Such growth would probably limit the permeability of the rock, reducing further ingress of S-bearing solutions. Complete silicification may, therefore, be a limiting factor in the alteration of the monazite-(Ce) to S-bearing monazite-(Ce).

\section{Source of elements in the S-bearing monazite}

Most of the elements in the S-bearing monazite are probably derived from the breakdown of local minerals. For instance, dissolution-precipitation textures of the core monazite-(Ce) grains indicate that these are the source for $\mathrm{P}$ and $R E E$ (Fig. $3 b-e$ ). Strontium may also be derived, in part, from the core monazite-(Ce) grains, but is probably derived predominantly from the release of $\mathrm{Sr}$ from the breakdown and silicification of dolomite. Dolomite breakdown is also the probable source of Ca. Owing to a lack of sulfide minerals in the carbonatite and surrounding Etusis schists and quartzites, breakdown of local sulfide minerals is a negligible source of sulfur for forming the S-bearing monazite-(Ce). An alternative source is the extensive gypcrete formations occurring along the coast of the Namib Desert, up to $70 \mathrm{~km}$ inland (Ekardt et al., 2001). The exact source of the $\mathrm{S}$ in the gypcrete is enigmatic, but possibilities include marine-derived, fog-borne $\mathrm{H}_{2} \mathrm{~S}$ (Brüchert et al., 2009) or dimethylsulfide (Ekardt and Spiro, 1999). While Eureka is located slightly further inland $(\sim 90 \mathrm{~km}$ from the coast) than the limit of gypcrete formation, wind-blown transport of gypsum has also been suggested as a source of sulfate for inland weathering (Ekardt et al., 2001). Sulfur isotope analyses would help further address this question, but are beyond the scope of the present study.

\section{Conclusions and implications}

Sulfur-bearing monazite-(Ce) occurs in silicified carbonatite at Eureka, Namibia, forming rims up to $\sim 0.5 \mathrm{~mm}$ thick on earlierformed monazite-(Ce) megacrysts. We present new XPS data which proves for the first time that the sulfur is predominantly accommodated as sulfate, via a clino-anhydrite-type coupled substitution mechanism. This largely confirms the assumption that $\mathrm{S}$ uptake into monazite-(Ce) is limited to oxidising conditions only, controlled by the oxidation state of the host rock (e.g. Laurent et al., 2016). Nonetheless, minor sulfide and sulfite peaks in the $\mathrm{X}$-ray photoelectron spectra suggest that more complex substitution mechanisms incorporating $\mathrm{S}^{2-}$ and $\mathrm{S}^{4+}$ are possible and that a more cautious approach for interpreting crystallisation environment from the presence of $S$ in monazite is warranted. Incorporation of $S^{6+}$ through clino-anhydrite-type substitution invariably results in an excess of $M^{2+}$ cations, which previous workers have suggested is accommodated by auxiliary substitution of $\mathrm{OH}^{-}$for $\mathrm{O}^{2-}$. However, our new Raman data show no indication of $\mathrm{OH}^{-}$, and instead we suggest charge imbalance is accommodated through $\mathrm{F}^{-}$substituting for $\mathrm{O}^{2-}$. The accommodation of $\mathrm{S}$ in the monazite-(Ce) results in considerable structural distortion which can account for relatively high contents of ions with radii beyond those normally found in monazite-(Ce), such as the HREE, Mo, $\mathrm{Zr}$ and $\mathrm{V}$.

In contrast to S-bearing monazite-(Ce) in other carbonatites, S-bearing monazite-(Ce) at Eureka formed through a prolonged weathering process. This is indicated predominantly by the localisation of the S-bearing monazite-(Ce) to silicified rocks which are constrained to the upper-most $5 \mathrm{~m}$ of exposure. $\mathrm{Ca}, R E E$ and $\mathrm{P}$ were derived from the local dissolution monazite-(Ce) and dolomite, and S-bearing monazite formed via a coupled dissolutionprecipitation mechanism. We suggest that $S$ is sourced via protracted aeolian input, as is the case for local gypcrete formations. While large S-bearing monazite-(Ce) grains are likely to be rare in the geological record, formation of secondary S-bearing monazite-(Ce) in these conditions may be a feasible mineral for dating palaeo-weathering, especially weathered carbonatites. Cosubstitution of $\mathrm{PbSO}_{4}$ during clino-anhydrite exchange is a notable challenge for dating S-bearing monazite-(Ce) (Krenn et al., 2011). Nonetheless, at Eureka the ${ }^{208} \mathrm{~Pb}$ concentration in the S-bearing monazite- $(\mathrm{Ce})$ is approximately half that of the original grain, while $\mathrm{U}$ contents are higher.

Acknowledgements. Pete Siegfried (GeoAfrica) and Tim Smalley (E-Tech Metals) are both thanked for suggesting the importance of weathering at Eureka. Jindrich Kynický is thanked for supplying an apatite sample from Slyudjanka. The original sampling and fieldwork was funded by a Society of Economic Geologists Hugh McKinstry Fund award to SBF, with additional funding from the NERC SoS RARE consortium (NE/M011429/1; SBF, MS, MBA, DAB, DA and FW) and a NERC Industrial Innovation Fellowship (NE/R013403/1) to SBF. DA and MBA acknowledge the Brazilian research foundation FAPESP (process 2014/50819-9) for financial support. The authors are grateful for the thoughtful reviews of Martin Ondrejka, Callum J Hetherington and Jean-Marc Montel, as well as the editorial handling of Éimear Deady, Stuart Mills and Helen Kerbey. 
Supplementary material. To view supplementary material for this article, please visit https://doi.org/10.1180/mgm.2019.79

\section{References}

Abraham K.M. and Chaudhri S.M. (1986) The lithium surface film in the $\mathrm{Li} / \mathrm{SO}_{2}$ cell. Journal of the Electrochemical Society, 133, 1307-1311.

Andreoli M.A.G., Smith C.B., Watkeys M., Moore J.M., Ashwal L.D. and Hart R.J. (1994) The Geology of the Steenkampskraal monazite deposit, South Africa: Implications for REE-Th-Cu mineralisation in charnockitegranulite terranes. Economic Geology, 89, 994-1016.

Ayers J.C., Loflin M., Miller C.F., Barton M.D. and Coath C.D. (2006) In situ oxygen isotope analysis of monazite as a monitor of fluid infiltration during contact metamorphism: Birch Creek Pluton aureole, White Mountains, eastern California. Geology, 34, 653-656.

Beall G.W., Boatner L.A., Mullica D.F. and Milligan W.O. (1981) The structure of cerium orthophosphate, a synthetic analogue of monazite. Journal of Inorganic and Nuclear Chemistry, 43, 101-105.

Begun G.M., Beall G. W., Boatner L.A. and Gregor, W.J. (1981) Raman spectra of the rare earth orthophosphates. Journal of Raman Spectroscopy, 11, 273-278.

Bermanec V., Tibljaš D., Gessner M. and Kniewald G. (1988) Monazite in hydrothermal veins from Alinci, Yugoslavia. Mineralogy and Petrology, 38, $139-150$.

Borg I.Y. and Smith D.K. (1975) A high pressure polymorph of $\mathrm{CaSO}_{4}$. Contributions to Mineralogy and Petrology, 50, 127-133.

Bradbury S.E. and Williams Q. (2009) X-ray diffraction and infrared spectroscopy of monazite-structured $\mathrm{CaSO}_{4}$ at high pressures: Implications for shocked anhydrite. Journal of Physics and Chemistry of Solids, 70, 134-141.

Broom-Fendley S., Wall F., Spiro B. and Ullmann C.V. (2017) Deducing the source and composition of rare earth mineralising fluids in carbonatites: insights from isotopic $\left(\mathrm{C}, \mathrm{O},{ }^{87} \mathrm{Sr} /{ }^{86} \mathrm{Sr}\right)$ data from Kangankunde, Malawi. Contributions to Mineralogy and Petrology, 172, 96.

Brounce M., Boyce J., McCubbin F.M., Humphreys J., Reppart J., Stolper E. and Eiler J. (2019) The oxidation state of sulfur in lunar apatite. American Mineralogist, 104, 307-312.

Brüchert V., Currie B. and Peard K.R. (2009) Hydrogen sulphide and methane emissions on the central Namibian shelf. Progress in Oceanography, 83, 169-179.

Budzyń B., Konečný P. and Kozub-Budzyń G.A. (2015) Stability of monazite and disturbance of the Th- $\mathrm{U}-\mathrm{Pb}$ system under experimental conditions of $250-350^{\circ} \mathrm{C}$ and $200-400 \mathrm{MPa}$. Annales Societatis Geologorum Poloniae, 85, $405-424$.

Budzyń B., Harlov D.E., Kozub-Budzyń G.A. and Majka J. (2016) Experimental constraints on the relative stabilities of the two systems monazite-(Ce) - allanite-(Ce) - fluorapatite and xenotime-(Y) - (Y, HREE)-rich epidote - (Y,HREE)-rich fluorapatite, in high $\mathrm{Ca}$ and $\mathrm{Na}-\mathrm{Ca}$ environments under P-T conditions of $200-1000 \mathrm{MPa}$ and $450-750^{\circ} \mathrm{C}$. Mineralogy and Petrology, 111, 183-217.

Bulakh A.G., Nesterov A.R., Zaitsev A.N., Pilipiuk A.N., Wall F. and Kirillov A.S. (2000) Sulfur-containing monazite-(Ce) from late-stage mineral assemblages at the Kandaguba and Vuoriyarvi carbonatite complexes, Kola peninsula, Russia. Neues Jahrbuch für Mineralogie - Monatshefte, 5, 217-233.

Burger A.J., von Knorring O. and Clifford T.N. (1965) Mineralogical and radiometric studies of monazite and sphene occurrences in the Namib Desert, South-West Africa. Mineralogical Magazine, 35, 519-528.

Bustillo M.A. (2010) Silicification of Continental Carbonates. Developments in Sedimentology, 62, 153-178.

Cabella R., Lucchetti G. and Marescotti P. (2001) Authigenic monazite and xenotime from peletic metacherts in pumpellyite-actinolite facies conditions, Sestri-Voltaggio Zone, Central Liguria, Italy. The Canadian Mineralogist, 39, 717-727.

Cetiner Z.S., Wood S.A., and Gammons C.H. (2005) The aqueous geochemistry of the rare earth elements. Part XIV. The solubility of rare earth element phosphates from 23 to $150^{\circ} \mathrm{C}$. Chemical Geology, 217, 147-169.

Chakhmouradian A.R. and Mitchell R.H. (1999) Niobian ilmenite, hydroxylapatite and sulfatian monazite; alternative hosts for incompatible elements in calcite kimberlite from Internatsional'naya, Yakutia. The Canadian Mineralogist, 37, 1177-1189.

Chakhmouradian A.R. and Wall F. (2012) Rare earth elements: minerals, mines, magnets (and more). Elements, 8, 333-340.

Chen W., Honghui H., Bai T. and Jiang S. (2017) Geochemistry of monazite within carbonatite related REE deposits. Resources, 6, doi:10.3390/ resources6040051

Cherniak D.J., Watson E.B., Grove M., and Harrison T.M. (2004) Pb diffusion in monazite: a combined RBS/SIMS study. Geochimica et Cosmochimica Acta, 68, 829-840.

Cooper D.C., Basham I.R. and Smith T.K. (1983) On the occurrence of an unusual form of monazite in panned stream sediments in Wales. Geological Journal, 18, 121-127.

Čopjaková R., Novák M. and Franců E. (2011) Formation of authigenic monazite-(Ce) to monazite-(Nd) from Upper Carboniferous graywackes of the Drahany Upland: Roles of the chemical composition of host rock and burial temperature. Lithos, 127, 373-385.

Cressey G., Wall F. and Cressey B.A. (1999) Differential REE uptake by sector growth of monazite. Mineralogical Magazine, 63, 813-828.

Crichton W.A., Parise J.B., Antao S.M. and Grzechnik A. (2005) Evidence for monazite-, barite-, and $\mathrm{AgMnO}_{4}$ (distorted barite)-type structures of $\mathrm{CaSO}_{4}$ at high pressure and temperature. American Mineralogist, 90, 22-27.

Cuney M. and Kyser K. (2015) Thorium deposits. Pp. 319-334 in: Geology and Geochemistry of Uranium and Thorium Deposits (M. Cuney and K. Kyser, editors). Mineralogical Association of Canada Short Course Series, 46.

Doroshkevich A.G., Ripp G.S. and Moore K.R. (2001) Genesis of the Khaluta alkaline-basic $\mathrm{Ba}-\mathrm{Sr}$ carbonatite complex (West Transbaikala, Russia). Mineralogy and Petrology, 98, 245-268.

Dunai T. (1989) Petrographische, Geochemische und Lagerstättenkundliche Untersuchungen an Karbonatitgängen auf der Farm Eureka $\mathrm{Nr}$ 99, Damaraland, Namibia. Diploma dissertation [in German], Heidelberg University, Germany.

Dunai T., Stoessel G.F.U. and Ziegler U.R.F. (1989) A Sr isotope study of the Eureka Carbonatite, Damaraland, Namibia. Communications of the Geological Survey of Namibia, 5, 91-92.

Ekardt F.D. and Spiro B. (1999) The origin of sulphur in gypsum and dissolved sulphate in the Central Namib Desert, Namibia. Sedimentary Geology, 123, 255-273.

Ekardt F.D., Drake N., Goudie A.S., White K. and Viles H. (2001) The role of playas in pedogenic gypsum crust formation in the Central Namib Desert: a theoretical model. Earth Surface Processes and Landforms, 26, 1177-1193.

Engi M. (2017) Petrochronology based on REE-minerals: monazite, allanite, xenotime, apatite. Pp. 365-418 in: Petrochronology: Methods and Applications (M.J. Kohn, M. Engi, and P. Lanari, editors). Reviews in Mineralogy and Geochemistry, 83. Mineralogical Society of America and the Geochemical Society, Chantilly, Virginia, USA.

Engi M., Lanari P. and Kohn M.J. (2017) Significant ages - an introduction to petrochronology. Pp. 1-12 in: Petrochronology: Methods and Applications (M.J. Kohn, M. Engi, and P. Lanari, editors). Reviews in Mineralogy and Geochemistry, 83. Mineralogical Society of America and the Geochemical Society, Chantilly, Virginia, USA.

Enkhbayar D., Sea J., Choi S-G., Lee Y.J. and Batmunkh E. (2016) Mineral Chemistry of REE-rich apatite and sulfur-rich monazite from the Mushgai Khudag, Alkaline Volcanic-Plutonic Complex, South Mongolia. International Journal of Geosciences, 7, 20-31.

Ewing R.C. and Wang L. (2002) Phosphates as Nuclear Waste Forms. Pp. 673699 in: Phosphates (M.L. Kohn, J. Rakovan and J.M. Hughes, editors). Reviews in Mineralogy and Geochemistry, 48. Mineralogical Society of America and the Geochemical Society, Washington, DC.

Förster, H.J. (1998) The chemical composition of REE-Y-Th-U-rich accessory minerals in peraluminous granites of the Erzgebirge-Fichtelgebirge region, Germany; Part I, The monazite-(Ce)-brabantite solid solution series. American Mineralogist, 83, 259-272.

Gardés E., Jaoul O., Montel J-M., Seydoux-Guillaume A-M. and Wirth R. (2006) $\mathrm{Pb}$ diffusion in monazite: An experimental study of $\mathrm{Pb}^{2+}+\mathrm{Th}^{4+}$ $\Leftrightarrow 2 \mathrm{Nd}^{3+}$ interdiffusion. Geochimica et Cosmochimica Acta, 70, 2325-2336. 
Gardés E., Montel J-M., Seydoux-Guillaume A-M. and Wirth R. (2007) Pb diffusion in monazite: New constraints from the experimental study of $\mathrm{Pb}^{2+}$ $\Leftrightarrow=>\mathrm{Ca}^{2+}$ interdiffusion. Geochimica et Cosmochimica Acta, 71, 4036-4043.

Grand'Homme A., Janots E., Seydoux-Guillaume A.M., Guillaume D., Magnin V., Hövelmann J., Höschen C. and Boiron M.C. (2018) Mass transport and fractionation during monazite alteration by anisotropic replacement. Chemical Geology, 484, 51-68.

Gonçalves G.O., Lana C., Scholz R., Buick I.S., Gerdes A., Kamo S.L., Corfu F., Marinho M.M., Chaves A.O., Valeriano C. and Nalini Jr H.A.N. (2016) An assessment of monazite from the Itambé pegmatite district for use as $\mathrm{U}-\mathrm{Pb}$ isotope reference material for microanalysis and implications for the origin of the "Moacyr" monazite. Chemical Geology, 424, 30-50.

Gonçalves G.O., Lana C., Scholz R., Buick I.S., Gerdes A., Kamo S.L., Corfu F., Rubatto D., Wiedenbeck M., Nalini Jr. H.A.M. and Oliveira L.C.A. (2018) The Diamantina monazite: A new low-Th reference material for microanalysis. Geostandards and Geoanalytical Research, 42, 25-47.

Harlov D.E., and Hetherington C.J. (2010) Partial high-grade alteration of monazite using alkali-bearing fluids: experiment and nature. American Mineralogist, 95, 1105-1108.

Harlov D.E., Wirth R., and Hetherington C.J. (2011) Fluid-mediated partial alteration in monazite: the role of coupled dissolution-reprecipitation in element redistribution and mass transfer. Contributions to Mineralogy and Petrology, 162, 329-348.

Hetherington C.J., Harlov D.E. and Budzyń B. (2010) Experimental metasomatism of monazite and xenotime: mineral stability, REE mobility and fluid composition. Mineralogy and Petrology, 99, 165-184.

Hetherington C.J., Backus E.L., McFarlane C.R.M., Fisher C.M. and Pearson D.G. (2018) Origins of textural, compositional, and isotopic complexity in monazite and its petrochronological analysis. Pp. 63-90 in: Microstructural Geochronology: Planetary Records Down to Atom Scale, Geophysical Monograph 232, First Edition (D.E. Moser, F. Corfu, J.R. Darling, S.M. Reddy, and K. Tait, editors). John Wiley \& Sons.

Jercinovic M.J., and Williams M.L. (2005) Analytical perils (and progress) in electron microprobe trace element analysis applied to geochronology: Background acquisition, interferences, and beam irradiation effects. American Mineralogist, 90, 526-546.

Kahn J.S. (1975) High-pressure phase transformation of $\mathrm{CaSO}_{4}$ (Anhydrite) during a nuclear explosion. Science, 189, 454-455.

Kim Y.J., Konecke B., Fiege A., Simon A. and Becker U. (2017) An ab initio study of the energetics and geometry of sulfide, sulfite, and sulfate incorporation into apatite: The thermodynamic basis for using this system as an oxybarometer. American Mineralogist, 102, 1646-1656.

Kolitsch U., and Holtstam D. (2004) Crystal chemistry of REEXO ${ }_{4}$ compounds $(X=\mathrm{P}, \mathrm{As}, \mathrm{V})$. II. Review of $\mathrm{REEXO}_{4}$ compounds and their stability fields. European Journal of Mineralogy, 16, 117-126.

Konecke B.A., Fiege A., Simon A.C., Parat F. and Stechern A. (2017a) Co-variability of $\mathrm{S}^{6+}, \mathrm{S}^{4+}$, and $\mathrm{S}^{2-}$ in apatite as a function of oxidation state: Implications for a new oxybarometer. American Mineralogist, 102, 548-557.

Konecke B.A., Fiege A., Simon A.C. and Holtz F. (2017b) Cryptic metasomatism during late-stage lunar magmatism implicated by sulfur in apatite. Geology, 45, 739-742.

Krenn E., Putz H., Finger F. and Paar W.H. (2011) Sulfur-rich monazite with high common $\mathrm{Pb}$ in ore-bearing schists from the Schellgaden mining district (Tauern Window, Eastern Alps), Mineralogy and Petrology, 102, 51-62.

Kukharenko A.A., Bulakh A.G. and Baklanova (1961) Sulphate-monazite from the carbonatites of the Kola Peninsula. Zapiski Vsesoyuznogo Mineralogicheskogo Obshchestva, 90, 373-381 [in Russian].

Laurent A.T., Seydoux-Guilaume A-M., Duchene S., Bingen B., Bosse V. and Datas L. (2016) Sulphate incorporation in monazite lattice and dating the cycle of sulphur in metamorphic belts. Contributions to Mineralogy and Petrology, 171, 94.

Lazareva E.V., Zhmodik S.M., Dobretsov N.L., Tolstov A.V., Shcherbov B.L., Karmanov N.S., Gerasimov E.Yu. and Bryanskaya A.V. (2015) Main minerals of abnormally high-grade ores of the Tomtor deposit (Arctic Siberia). Russian Geology and Geophysics, 56, 844-873.
Lehmann B., Nakai S, Höhndorf A., Brinckmann J., Dulski P., Hein U.F. and Masuda A. (1994) REE mineralization at Gakara, Burundi: Evidence for anomalous upper mantle in the western Rift Valley. Geochimica et Cosmochimica Acta, 58, 985-992.

Lenz C., Nasdala L., Talla D., Hauzenberger C., Seitz R. and Kolitsch U. (2015) Laser-induced $R E E^{3+}$ photoluminescence of selected accessory minerals An "advantageous artefact" in Raman spectroscopy. Chemical Geology, $415,1-16$.

Lottermoser B.G. (1990) Rare-earth element mineralisation within the Mt. Weld carbonatite laterite, Western Australia. Lithos, 24, 151-167.

McDonough W.F. and Sun S. (1995) The composition of the earth. Chemical Geology, 120, 223-253.

McFarlane C.R.M. and McCulloch M.T. (2007) Coupling of in situ Sm-Nd systematics and $\mathrm{U}-\mathrm{Pb}$ dating of monazite and allanite with applications to crustal evolution studies. Chemical Geology, 245, 45-60.

Mesarwi A. and Ignatiev A. (1993) Interaction of Y overlayers with the GaAs (100) surface and oxidation of the Y/GaAs interface. Surface Science, 282, 371-379.

Miller R. McG. (1983) The Pan-African Damara Orogen of South West Africa/ Namibia. Pp. 431-515 in: Evolution of the Damara Orogen of South West Africa/Namibia (R. McG. Miller, editor). Special Publications of the Geological Society of South Africa, 11.

Miller R. McG (2008) The Geology of Namibia. Geological Survey of Namibia, Windhoek.

Montel J-M., Foret S., Veschambre M., Nicollet C. and Provost A. (1996) Electron microprobe dating of monazite. Chemical Geology, 131, 37-53.

Montel J-M., Razafimahatratra D., de Parseval P., Poitrasson F., Moine B., Seydoux-Geuillaume A-M., Pik R., Arnaud N. and Gibert F. (2018) The giant monazite crystals from Manangotry (Madagascar). Chemical Geology, 484, 36-50.

Nash D.J. and Shaw P.A. (1998) Silica and carbonate relationships in silcretecalcrete intergrade duricrusts from the Kalahari of Botswana and Namibia. Journal of African Earth Sciences, 27, 11-25.

Ni Y., Hughes J.M. and Mariano A.N. (1995) Crystal chemistry of the monazite and xenotime structures. American Mineralogist, 80, 21-26.

Nikolenko A.M., Redina A.A., Doroshkevich A.G., Prokpyv I.R., Rafozin A.L. and Vladykin N.V. (2018) The origin of magnetite-apatite rocks of Mushgai-Khudag Complex, South Mongolia: mineral chemistry and studies of melt and fluid inclusions. Lithos, 320-321, 567-582.

Ntiharirizwa S., Boulvais P., Poujol M., Branquet Y., Morelli C., Ntungwanayo J. and Midende G. (2018) Geology and U-Th-Pb Dating of the Gakara REE Deposit, Burundi. Minerals, 8, doi:10.3390/min8090394

Oelkers E.H. and Montel J-M. (2008) Phosphates and nuclear waste storage. Elements, 4, 113-116.

Oliveira S.M.B. and Imbernon R.A.L. (1998) Weathering alteration and related REE concentration in the Catalão I carbonatite complex, central Brazil. Journal of South American Earth Sciences, 11, 379-388.

Ondrejka M., Uher P., Pršek J. and Ozdín D. (2007) Arsenian monazite-(Ce) and xenotime-(Y), REE arsenates and carbonates from the Tisovec-Rejkovo rhyolite, Western Carpathians, Slovakia: Composition and substitutions in the (REE,Y)XO $\mathrm{O}_{4}$ system $(X=\mathrm{P}, \mathrm{As}, \mathrm{Si}, \mathrm{Nb}, \mathrm{S})$. Lithos, 95, 116-129.

Ondrejka M., Putiš M, Uher P., Schmiedt I., Pukančík L. and Konečný P. (2016) Fluid-driven destabilization of REE-bearing accessory minerals in the granitic orthogneisses of North Veporic basement (Western Carpathians, Slovakia). Mineralogy and Petrology, 110, 561-580.

Pan Y.M. and Fleet M.E. (2002) Compositions of the apatite-group minerals: substitution mechanisms and controlling factors. Pp. 13-49 in: Phosphates (M.L. Kohn, J. Rakovan and J.M. Hughes, editors). Reviews in Mineralogy and Geochemistry, 48. Mineralogical Society of America and the Geochemical Society, Washington, DC.

Parrish R.R. (1990) U-Pb dating of monazite and its application to geological problems. Canadian Journal of Earth Sciences, 27, 1431-1450.

Paton C., Hellstrom J., Paul B., Woodhead J. and Hergt J. (2011) Iolite: Freeware for the visualisation and processing of mass spectrometric data. Journal of Analytical Atomic Spectrometry, 26, 2508-2518.

Poitrasson F., Oelkers E., Schott J., and Montel J-M (2004) Experimental determination of synthetic $\mathrm{NdPO}_{4}$ monazite end-member solubility in water 
from $21^{\circ} \mathrm{C}$ to $300^{\circ} \mathrm{C}$ : implications for rare earth element mobility in crustal fluids. Geochimica et Cosmochimica Acta, 68, 2207-2221.

Prokopyev I.R., Doroshkevich A., Ponomarchuk A.V. and Sergeev S.A. (2017) Mineralogy, age and genesis of apatite-dolomite ores at the Seligdar apatite deposit (Central Aldan, Russia). Ore Geology Reviews, 81, 296-308.

Pršek J., Ondrejka M., Bačík P., Budzyń B. and Uher P. (2010) Metamorphichydrothermal REE minerals in the Bacúch magnetite deposit, Western Carpathians, Slovakia: $(\mathrm{Sr}, \mathrm{S})$-rich monazite-(Ce) and Nd-dominant hingganite. The Canadian Mineralogist, 48, 81-94.

Putnis A. (2002) Mineral replacement reactions: from macroscopic observations to microscopic mechanisms. Mineralogical Magazine, 66, 689-708.

Putnis A. (2009) Mineral replacement reactions. Pp. 87-124 in: Thermodynamics and Kinetics of Water-Rock Interaction (E.H. Oelkers and J. Schott, editors). Reviews in Mineralogy and Geochemistry, 70. Mineralogical Society of America and the Geochemical Society, Chantilly, Virginia, USA.

Putnis C.V. and Ruiz-Agudo E. (2013) The mineral-water interface: where minerals react with the environment. Elements, 9, 177-182.

Ragettli R.A., Hebeda E.H., Signer P. and Wieler R. (1994) Uranium-xenon chronology: precise determination of $\lambda_{\mathrm{sf}^{+}}{ }^{136} \mathrm{Y}_{\mathrm{sf}}$ for spontaneous fission of ${ }^{238}$ U. Earth and Planetary Science Letters, 128, 653-670.

Rasmussen B. and Muhling J.R. (2007) Monazite begets monazite: evidence for dissolution of detrital monazite and reprecipitation of syntectonic monazite during low-grade regional metamorphism. Contributions to Mineralogy and Petrology, 154, 675-689.

Sadove G., Konecke B.A., Fiege A. and Simon A.C. (2019) Structurally bound $S^{2-}, S^{1-}, S^{4+}, S^{6+}$ in terrestrial apatite: The redox evolution of hydrothermal fluids at the Phillips mine, New York, USA. Ore Geology Reviews, 107, 1084-1096.

Seydoux-Guillaume A-M., Deschanels X., Baumier C., Neumeier S., Weber W.J. and Peuget S. (2018) Why natural monazite never becomes amorphous: Experimental evidence for alpha self-healing. American Mineralogist, 103, 824-827.

Shannon R.D. (1976) Revised effective ionic radii and systematic studies of interatomic distances in halides and chalcogenides. Acta Crystallographica, A32, 751-767.

Silva E.N., Ayala A.P., Guedes I., Paschoal C.W.A., Moreira R.L., Loong C.K. and Boatner L.A. (2006) Vibrational spectra of monazite-type rare-earth orthophosphates. Optical Materials, 29(2-3), 224-230.

Slezak P. and Spandler C. (2019) Carbonatites as recorders of mantle-derived magmatism and subsequent tectonic events: An example of the Gifford Creek Carbonatite Complex, Western Australia. Lithos, 328-329, 212-227.
Spear F.S. and Pyle J.M. (2002) Apatite, monazite, and xenotime in metamorphic rocks. Pp. 293-335 in: Phosphates (M.L. Kohn, J. Rakovan and J.M. Hughes, editors). Reviews in Mineralogy and Geochemistry, 48. Mineralogical Society of America and the Geochemical Society, Washington, DC.

Suzuki K. and Kato T. (2008) CHIME dating of monazite, xenotime, zircon and polycrase: Protocol, pitfalls and chemical criterion of possibly discordant age data. Gondwana Research, 14, 569-586.

Vasquez R.P. (1991) X-ray photoelectron spectroscopy study of Sr and Ba compounds. Journal of Electron Spectroscopy and Related Phenomenon, 56, $217-240$.

Viles H.A. and Goudie A.S. (2013) Weathering in the central Namib Desert, Namibia: Controls, processes and implications. Journal of Arid Environments, 93, 20-29.

von Knorring O. and Clifford T.N. (1960) On a skarn occurrence from the Namib desert near Usakos, South-West Africa. Mineralogical Magazine, 32, 650-653.

Voskoboinikova N. (1938) The mineralogy of the Slyudyanka deposits of lazurite. Zapiski Vserossiyskogo Mineralogicheskogo Obshchestva, 67, 601-622 [in Russian].

Wall F. (2004) An illustration of the evolution and alteration of carbonatites using REE, Sr-rich carbonatites at Nkombwa, Zambia. Pp. 49-68 in Deep-Seated Magmatism, its Sources and Their Relation to Plume Processes (N.V. Vladykin, editor). Russian Academy of Sciences, Irkutsk.

Wall F. (2014) Rare earth elements. Pp. 312-339 in: Critical Metals Handbook (A. Gunn, editor). Wiley, New York.

Wall F. and Mariano A. (1996) Rare earth minerals in carbonatites: a discussion centred on the Kangankunde Carbonatite, Malawi. Pp. 193-226 in: Rare Earth Minerals: Chemistry Origin and Ore Deposits (A.P. Jones, F. Wall and C.T. Williams, editors). Chapman and Hall, London.

Watts N.L. (1980) Quaternary pedogenic calcretes from the Kalahari (southern Africa): mineralogy, genesis and diagenesis. Sedimentology, 27, 661-686.

Williams C.T. (1996) Analysis of rare earth minerals. Pp. 193-226 in: Rare Earth Minerals: Chemistry Origin and Ore Deposits (A.P. Jones, F. Wall and C.T. Williams, editors). Chapman and Hall, London.

Williams M., Jercinovic M.J. and Hetherington C.J. (2007) Microprobe monazite geochronology: understanding geologic processes by integrating composition and chronology. Annual Review of Earth and Planetary Sciences, 35, 137-175.

Yu X.R., Liu F., Wang Z.Y. and Chen Y. (1990) Auger parameters for sulfurcontaining compounds using a mixed aluminum-silver excitation source. Journal of Electron Spectroscopy and Related Phenomena, 50, 159-166. 